Rhode Island College

Digital Commons @ RIC

$11-29-2018$

\title{
Haloperidol and Postoperative Nausea and Vomiting: A Systematic Review
}

Megan Collins

Follow this and additional works at: https://digitalcommons.ric.edu/etd

Part of the Perioperative, Operating Room and Surgical Nursing Commons

\section{Recommended Citation}

Collins, Megan, "Haloperidol and Postoperative Nausea and Vomiting: A Systematic Review" (2018). Master's Theses, Dissertations, Graduate Research and Major Papers Overview. 288.

https://digitalcommons.ric.edu/etd/288

This Major Paper is brought to you for free and open access by the Master's Theses, Dissertations, Graduate Research and Major Papers at Digital Commons @ RIC. It has been accepted for inclusion in Master's Theses, Dissertations, Graduate Research and Major Papers Overview by an authorized administrator of Digital Commons @ RIC. For more information, please contact digitalcommons@ric.edu. 
HALOPERIDOL AND

POSTOPERATIVE NAUSEA AND VOMITING:

A SYSTEMATIC REVIEW

by

\section{Megan Collins}

A Major Paper Submitted in Partial Fulfillment

of the Requirements for the Degree of

Master of Science in Nursing

in

The School of Nursing

Rhode Island College

2017 


\begin{abstract}
Postoperative nausea and vomiting (PONV) is a complication that affects up to $30 \%$ of the patients undergoing general surgery. This complication can be dangerous for patients, increase recovery time and decrease patient satisfaction scores. There are many different medications that have been used to prophylactically treat PONV including haloperidol. A systematic review was conducted to determine the efficacy of haloperidol as an antiemetic. Databases were searched and inclusion and exclusion criteria were applied to finalize the articles included. The PRISMA framework was used to guide the review and a total of five studies were critically analyzed. Two data collection tables were created for each article, one that illustrated the design of the study and one that illustrated the results. The CASP checklist was utilized to critically appraise each article. Finally, a cross study analysis was conducted to compare the studies. Haloperidol was studied alone and in combination with other antiemetic medications. Overall, these studies showed a decrease in PONV in patients medicated with haloperidol. Using haloperidol prophylactically, especially when utilized with multiple medications, decreased episodes of vomiting and levels of nausea. Haloperidol can be a useful and safe medication that anesthesia providers may utilize to prevent PONV. Further research is needed to study the impact on general surgery procedures and with larger samples.
\end{abstract}




\section{Table of Contents}

Background/Statement of the Problem .................................................................. 1

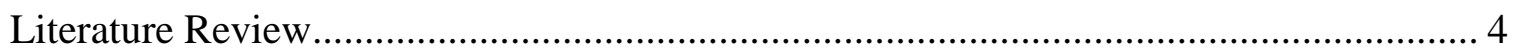

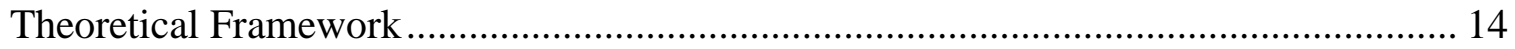

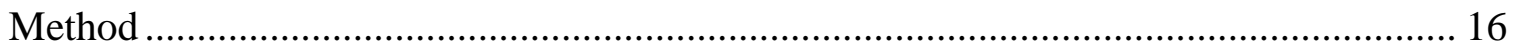

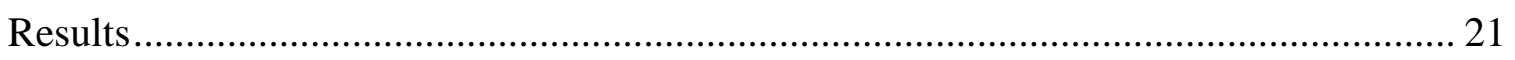

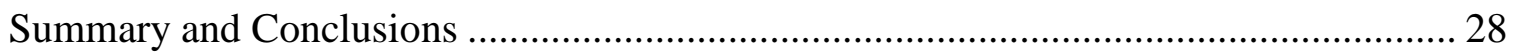

Recommendations and Implications for Advanced Nursing Practice ........................... 30

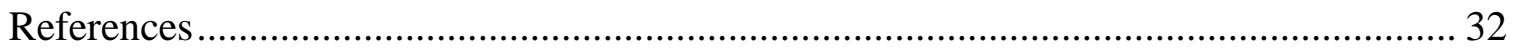

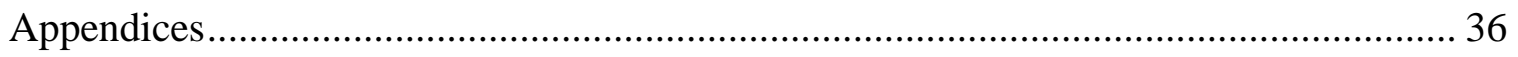


Haloperidol and Postoperative Nausea and Vomiting: A Systematic Review

\section{Background/Statement of the Problem}

Post-operative nausea and vomiting (PONV) has been a continuous problem for patients recovering from surgery. Postoperative nausea and vomiting is defined as any nausea, retching, or vomiting in the 24 period after surgery (Flood, Rathmell, \& Shafer, 2015). In 1914, the first journal of anesthesia published an article about prophylactically treating PONV. Even though it has been a source of conversation since then, it remains one of the most common complications of general anesthesia (Nagelhout \& Plaus, 2014). Incidence as high as 30\% in all patients and as high as $80 \%$ in cases where the patient was at high risk for PONV are reported (Pierre \& Whelan, 2013).

This common complication often increases recovery time, which may lead to an unexpected hospital stay or increased length of stay after the procedure (Flood et al., 2015). Vomiting or retching after surgery can be dangerous for the patient and cause further complications such as suture dehiscence and aspiration (Nagelhout \& Plaus, 2014). Postoperative nausea and vomiting is very uncomfortable for the patient and contributes to dissatisfaction scores for anesthesia providers (Flood et al., 2015). Patients have even ranked PONV as the most important clinical anesthesia complication to avoid, putting it ahead of other complications such as pain, intraoperative recall and gagging on the endotracheal tube (Flood et al).

When a patient goes under general anesthesia, there are many factors that can contribute to PONV. These include the medications used, such as the volatile anesthetics and opioids, as well as other factors such as the patient's anxiety, motion and surgical manipulation (Pierre \& Whelan, 2013). Volatile anesthetics have been shown to increase 
PONV two-fold and nitrous oxide has also been shown to have an increased risk. Adding opioids throughout the case can increase PONV in a dose-dependent manner (Pierre \& Whelan). All of these combined provide an environment where PONV can easily occur. There are identified risk factors that place patients are increased risk for PONV. These risks are divided into patient specific, anesthesia related, and surgery related (Nagelhout \& Plaus, 2014). Patient specific risk factors include female gender, age less than 50, nonsmokers, history of PONV and history of motion sickness. Anesthetic related factors include use of volatile anesthetics, use of nitrous oxide and intraoperative/postoperative use of opioids. Surgery related risk factors include the duration of the surgery being more than one hour and the type of surgery. Laparoscopic surgery has been identified as one of the surgical procedures with a high incidence of PONV (Nagelhout \& Plaus). When a patient has several risk factors, it can increase the risk of PONV up to 80\% (Pierre \& Whelan, 2013).

To prevent the patient from having to experience PONV, a prophylactic approach has been used. To prophylactically treat a patient, especially one who has been determined as high risk, a multimodal approach works well due to the complexity of activating the vomiting center (Pierre \& Whelan, 2013). Postoperative nausea and vomiting is controlled in the brain at what is called the vomiting center. This is in the medulla oblongata and contains the nucleus of the tractus solitaries (NTS). Multiple neurotransmitters control the activity of this vomiting center. These neurotransmitters are dopamine, serotonin, substance $\mathrm{P}$, acetylcholine, gamma-aminobutyric and cannabinoids. PONV can also be activated through the chemoreceptor trigger zone (CRTZ) when the body detects noxious chemicals (Flood et al., 2015). The different medications can work 
independently to prevent nausea and vomiting, but when used in combination they also have additive effects (Pierre \& Whelan, 2013).

One of these medications is haloperidol, which is a butyrophenone, and has an antagonistic effect on the D2 dopamine receptors. Haloperidol is primarily used to treat schizophrenia and other psychiatric disorders but has other uses, such as a treatment for intractable hiccups. It also has antiemetic properties (Flood et al., 2015). Haloperidol does have side effects, especially at higher doses, such as cardiac arrhythmias, prolongation of the QTc interval, sedation, and extrapyramidal symptoms. These side effects provide some risk with using haloperidol as a prophylactic medication (Pierre \& Whelan, 2013).

The purpose of this systematic review is to review current evidence of how haloperidol effects postoperative nausea and vomiting in patients who have undergone a laparoscopic surgical procedure.

Next, a review of the literature will be presented. 


\section{Literature Review}

A review of the literature was conducted to examine information about PONV and the effects of haloperidol. Databases searched were PubMed, CINAHL, Medline, and google scholar. Search words included postoperative nausea and vomiting, treatment, causes, risk factors, haloperidol and laparoscopic surgery. Evidence-based reviews, randomized control trials, guidelines, quasi-experimental studies, and non-experimental studies were included in this literature review.

\section{Laparoscopic Surgical Procedures}

Laparoscopic surgery has greatly changed the way general, gynecological and urological surgery is done. The laparoscopic cholecystectomy is not only the most common laparoscopic surgical procedure performed, it is also now considered the gold standard for removing the gallbladder (Chamberlain \& Sakpal, 2009). A laparoscopic surgical procedure is considered a minimally invasive surgical procedure (Nagelhout \& Plaus, 2014). This allows a surgeon to perform a surgical procedure with less blood loss, decreased pain, and a quicker recovery for the patients. Although laparoscopic technique has been changing clinical practice for approximately 30 years, it was first used in 1901 for an endoscopic examination of the peritoneal cavity by a German surgeon. For 70

years after that surgery, there were surgeons who attempted to use a laparoscopic method. However, there were many complications during those times such as cautery injuries and perforations. As technology advanced, especially with videoscopic imaging being developed in the 1980’s, the first laparoscopic cholecystectomy was performed with video assistance by a French surgeon in 1988. With this successful procedure, the health 
care community began to pay attention to utilizing laparoscopic procedures (Nagelhout \& Plaus).

Now that these procedures can be done with video assistance, there are many advantages to them. Laparoscopic surgeries tend to be safer, less painful, minimally invasive and have a faster recovery time to normal function (Nagelhout \& Plaus, 2014). These procedures are usually associated with less blood loss, fewer blood transfusions, and less postoperative opioid requirements (Butterworth, Mackey \& Wasnick, 2013).

Although there are many benefits to laparoscopic surgical procedures, they are also complex and do have their own complications (Nagelhout \& Plaus, 2014). To perform a laparoscopic procedure, the surgeon creates a pneumoperitoneum where air or gas is instilled into the peritoneal cavity under pressure. This creates an area where the surgeon can visualize the field they are working on. The creation of this pneumoperitoneum is responsible for most of the complications seen with laparoscopic surgical procedures, including vascular or bowel injury and hemodynamic changes. These can be seen intraoperatively as well as postoperatively (Nagelhout \& Plaus). The other complication frequently seen with laparoscopic procedure is increased incidence of nausea and vomiting which is believed to be from the increased air or gas in the peritoneal cavity causing irritation (LiveStrong, 2015). Combining this irritation with other risk factors for PONV, such as anesthetic gases or opioids, creates a greater occurrence of PONV (LiveStrong).

\section{Postoperative Nausea and Vomiting}

Postoperative nausea and vomiting is one of the most common postoperative complications seen. It is defined as any nausea, retching, or vomiting occurring during 
the first 24 hours after surgery (Pierre \& Whelan, 2013). It is seen in 30\% of patients undergoing general anesthesia, and up to $80 \%$ of patients who have been identified as high risk patients (Pierre \& Whelan). Experiencing PONV can lead to prolonged recovery, unplanned or prolonged hospital admissions, poor satisfaction scores, and higher patient cost (Smith, H., Smith, E., \& Smith, B., 2012). This common complication is disliked by patients so intense that one study showed that patients ranked vomiting as more undesirable than gagging on the tracheal tube, incisional pain, recall, residual weakness, shivering, sore throat, and somnolence. Patients stated they were even willing to pay between $\$ 56-100$ for hypothetical effective antiemetic prophylaxis (Smith et al.). Also, it puts the patient at risk for further complications such as aspiration pneumonia, Boerhaave’s syndrome, subcutaneous emphysema, pneumothorax, rupture of the trachea, loss of vision, and suture dehiscence (Rusch, Eberhart, Wallenborn, \& Kranke, 2010).

Postoperative nausea and vomiting is controlled in the body from the vomiting center. This is an area in the medulla that receives signals and can trigger nausea and/or vomiting. The vomiting center also communicates with the chemoreceptor trigger zone which can trigger vomiting. These two areas have multiple receptors, which can cause them to be activated in many different ways. The receptors found here are histamine, serotonin, cholinergic, neurokinin-1 and D2 dopamine receptors. Due to the multiple ways these centers can be activated, there are many different ways which a patient can be treated for PONV (Chatterjee, Rudra \& Sengupta, 2011).

It is very important to prevent PONV whenever possible so that patients do not have to experience this complication. One study stated that while laparoscopic procedures usually are associated with short periods of hospitalization, PONV is being seen as the 
most common reason for prolongation of hospital stay after a laparoscopic cholecystectomy (Akkurt et al., 2009). This study compared recovery time of patients receiving propofol for anesthesia and patients receiving a general anesthetic gas, desflurane. There was a total of 68 patients who were included in this study. All patients were in the ASA class I or II and had a laparoscopic cholecystectomy. Five patients were excluded from this study, with 63 remaining who were then divided into two groups. In the propofol group, there was a significant decrease in PONV which coincided with a decrease in hospitalization time. Only two patients (6.7\%) in the propofol group had vomiting episodes, while 16 patients (53.3\%) in the desflurane group did. This was found to be statistically significant with $P<0.005$. Also, the patient satisfaction scores were significantly higher in the group that did not receive desflurane $(P<0.001)$ (Akkurt et al.).

\section{Risk Factors for Postoperative Nausea and Vomiting and Scoring Systems}

There are identified factors that can predict if a patient will be at higher risk for developing nausea and vomiting. There are patient specific factors, anesthesia related factors and surgery specific factors (Pierre, Benais \& Pouymayou, 2002). Patient specific risk factors include the female gender, age less than 50 , nonsmokers, and a history of PONV or motion sickness. Anesthesia related risk factors include the use of volatile anesthetics, nitrous oxide, and opioids. Surgery related risk factors include the duration of the surgery and the type of surgery (Nagelhout \& Plaus, 2014).

There have been several different scoring systems utilized to determine a patient's risk level. One of these scoring systems is called the Sinclair-score (Pierre et al., 2002). This system takes into account all three kinds of risk factors. Another scoring system is 
called the Apfel-score which examines four specific risk factors including female gender, previous history of PONV or motion sickness, non-smoking status, and postoperative use of opioids (Pierre et al.). Health care facilities have a protocol on which scoring systems, if any, are used to identify high risk patients and how those patients are managed. Some facilities lean towards a risk factor directed prophylaxis treatment, while other facilities have a set order for patients to be prophylactically treated (Wolf et al., 2016).

In a study that compared these two scoring systems, five hundred consecutive adult patients who were undergoing general anesthesia for a throat, thyroid, breast or gynecological procedure were included (Pierre et al., 2002). The authors excluded patients who had been premedicated for nausea and vomiting, which left 428 patients. Of those patients 50\% experienced PONV. It was found that the area under the receiver operating characteristic (ROC)-curve was significantly greater for the Apfel scoring system as compared to the Sinclair-scoring system, 0.71 vs 0.64 . An area under the ROCcurve of 1.0 represents a perfect discrimination in patients. Thus, these areas under the ROC-curve indicate that the Apfel scoring system is better at predicting the likelihood of PONV. The Apfel scoring system is relatively simple and easy for health care workers to use and help prevent PONV in high risk patients (Pierre et al.).

\section{Risk Factor-Directed Prophylaxis}

There are various theories about how risk factors effect prophylactically treating a patient. Some providers believe that all patients regardless of their risk factors should be treated liberally for PONV, while others believe that the use of any medication should be patient specific and based on their risk factors (Wolf et al., 2016). Wolf et al. examined the effectiveness of treating patients based on their risk factors for PONV. The study 
included 92 patients who had undergone strabismus surgery and included a mix of adult and pediatric patients. The Apfel-scoring system was used to determine if the patient was high risk. If the patient scored a 3-4 on the scale they were prophylactically treated with a multimodal approach which included multiple medications that effected different receptors. Their surgeries were done without a general anesthetic gas. Overall, 45 patients (49\%) were found to be in the high-risk category. There were 47 patients (51\%) that were put into the low-risk category. Out of all 92 participants, there were 16 (17\%) who experienced PONV. The adults that were high risk had an incidence of $8 \%(n=4)$ of PONV. The children who were in the high risk category had a 9\% $(n=4)$ incidence of PONV. Adults who were determined to be lower risk had an incident of $21 \%(n=10)$ and children had an incidence of $38 \%(n=17)$. The study concluded with advocating for a more liberal use of prophylactic medications regardless of what the patients risk score was based on how high PONV was even in the low risk group (Wolf et al.).

An evidence-based review discussed prophylactically treating patients for PONV based on risk factors (Rusch et al., 2010). The authors stated that PONV is a significant problem that should be adequately prevented and treated quickly if it occurs. The highest risk factors were identified as female gender, history of PONV or motion sickness, use of opioids during and after surgery, use of inhalation anesthetics and nitrous oxide and the duration of the surgery. This review focused on how risk-adapted prophylaxis compared to a fixed prophylaxis. It was stated that exclusively using a risk-adapted method did not provide any greater benefit than a fixed method where every patient is treated to prevent PONV. It also stated that patients that did fall into the high-risk categories required more 
than one drug to prevent PONV and recommended that they should always be treated with a multimodal prophylactic method (Rusch et al.).

\section{Multimodal Prophylaxis of Postoperative Nausea and Vomiting}

It has been shown that utilizing a multimodal approach to PONV can be very effective, even in patients that are at high risk. Gan et al. (2014) presented consensus guidelines for the management of PONV. These guidelines had eight goals: to understand who is at risk for PONV; establish factors that reduce these risks; determine the most effective drug therapy for prophylaxis; ascertain the best treatment for PONV, determine the best timing and dosage of prophylactic treatment; evaluate cost-effectiveness of management strategies; create an algorithm; and propose a research agenda for further research in this topic.

Due to the complex nature in which PONV occurs, it can be very beneficial to treat patients prophylactically with multiple drug classes (Gan et al., 2014). It has been shown that patients at moderate or high risk should always be treated with a combination of medications preoperatively and intraoperatively to prevent PONV. For example, serotonin antagonists, such as Zofran, have stronger antiemetic effects than antinausea effects where as dopamine antagonists, such as haloperidol, have stronger antinausea effects (Gan et al.). It is beneficial to the patient to give these medications in combination to get a decreased occurrence of PONV.

It has also been shown that medicating patients with two medications together, such as dexamethasone and Zofran, has a significantly higher efficacy than when either drug is given alone (Gan et al., 2014). In these current guidelines, the groups of medications that are recommended for prophylactic treatment are 5-HT3 receptor 
antagonists, Nk-1 receptor antagonists, corticosteroids, butyrophenones, antihistamines, anticholinergics, and phenothiazines. There are other medications such as propofol, gabapentin, and versed that have also shown antiemetic and/or antinausea properties (Gan et al.).

Chatterjee, Rudra and Sengupta (2011) stated that for patients in moderate and high risk groups, regional anesthesia should always be considered. This would greatly decrease the risk of PONV. However, if general anesthesia must be used the patient should receive combination antiemetic therapy. This has been shown to be superior to monotherapy as it allows multiple mechanisms of actions through different receptor sites to prevent PONV (Chatterjee et al.).

The effectiveness of using multiple medications to prophylactically treat PONV was demonstrated in a study by Biswas and Rudra (2003). This study included 120 patients who had gone under general anesthesia for a laparoscopic cholecystectomy. The patients were divided into two groups, one group received only granisetron and the other group received granisetron and dexamethasone, both of which medications have been shown to decrease PONV. In the group with only the granisetron $83 \%(n=50)$ of the patients did not experience PONV within the first 24 hour period after surgery. In the group with both the granisetron and the dexamethasone, 95\% $(n=57)$ of the patients did not experience PONV. Prophylactically treating with multiple medications that work on different receptor sites has a greater effect (Biswas \& Rudra).

\section{Butyrophenones}

Butryophenones are a group of medications that work on the D2 dopamine receptors (Chatterjee et al., 2011). The two drugs in this class that have antiemetic 
properties and are used to prevent PONV are droperidol and haloperidol. Prior to 2001, droperidol was a very popular medication used alone and in combination for prevention of PONV. It was used at low doses, $0.625-1.25 \mathrm{mg}$ and it was effective. However, this drug class has many side effects and in 2001, the FDA released a black box warning for droperidol. This was due to a risk of QT prolongation which led to arrhythmias when this drug was used. The black box warning referred to using much higher doses of doperidol than would be used for PONV, however it is mandatory to now have cardiac monitoring on the patient when using this medication (Chatterjee et al).

Haloperidol also has antiemetic properties, and has been studied more since the black box warning on droperidol. Haloperidol was originally used to treat psychiatric disorders, and still is to this day. However, to prevent PONV, the dose used is 0.5-2 mg (Gan et al., 2014). At this lower dose other side effects such as sedation and cardiac arrhythmias were not seen with haloperidol though it does still carry a risk of QTc prolongation. Aouad et al. (2007) compared the effects of haloperidol and Zofran. This study included 93 females undergoing a gynecologic procedure under general anesthesia. When $1 \mathrm{mg}$ of haloperidol was compared with $4 \mathrm{mg}$ of Zofran, there was no difference in the QTc effect. There was also no significant difference in the PONV incidence; $40.7 \%$ ( $n=11$ ) of the haloperidol group experienced PONV and the Zofran group had an incidence of 48.2\% ( $n=13)$ (Aouad et al.).

Another known side effect of haloperidol is extrapyramidal symptoms. However, a meta-analysis of haloperidol as an antiemetic showed that only one in 806 patients who were given 4 mg of haloperidol exhibited any extrapyramidal symptoms (Buttner, Walder, Elm \& Tramer, 2004). Out of all the studies that the meta-analysis discussed a 
total of 1,397 patients received haloperidol at different doses and no patients receiving a dose of haloperidol less than 4 mg exhibited extrapyramidal symptoms (Buttner et al). Since haloperidol is a dopamine antagonist it should be used with extreme caution with any patients who have Parkinson's disease, restless leg syndrome, or any other disease that is related to a dopamine insufficiency (Flood et al., 2015).

The Buttner et al. (2004) meta-analysis examined a total of 21 studies using haloperidol to treat nausea and vomiting. However, this literature review will focus on the evidence combined from four studies in the meta-analysis that examined the effect of haloperidol on preventing PONV. Intravenous dosages were tested at $5 \mathrm{mg}$ and $4 \mathrm{mg}$. Both significantly decreased nausea and vomiting, although the antinausea effect was greater. With haloperidol, the average report of nausea was $16.4 \%(n=90 / 548)$, whereas with the placebo it was $43.8 \%(n=237 / 541)$. The results of this meta-analysis provide evidence that haloperidol is effective as an antiemetic. This systematic review will focus on more recent studies to evaluate the most up to date evidence on the topic.

Next, the theoretical framework guiding this systematic review will be discussed. 


\section{Theoretical Framework}

The PRISMA framework was used to guide this project. PRISMA is an evidencebased set of items that helps authors improve the reporting in a systematic review as well as assess the strengths and weaknesses of a systematic review (Moher, Liberati, Tetzlaff \& Altman, 2009). The PRISMA statement consists of a flow diagram and a checklist. The flow diagram is illustrated in Appendix A and guides the user through identifying, screening, and checking eligibility of the articles that will ultimately be included in the systematic review (Moher et al).

The checklist assists the author in structuring and writing the systematic review. The checklist, shown in Appendix B, consists of 27 items and includes major sections of a systematic review and what is to be included in each section (Moher et al., 2009). This is helpful to make sure that every part necessary to a systematic review is included. Inclusion and exclusion criteria will be applied to select articles that will be analyzed. Utilizing PRISMA as a framework will help to create a thorough and pertinent systematic review (Moher et al.).

In addition to PRISMA, the Critical Appraisal Skills Programme (CASP) was used to evaluate each article that was selected to be included in the systematic review. The purpose of CASP is to help determine the scientific integrity of the research being evaluated. There is a CASP checklist, illustrated in the methods section, exclusively for systematic reviews that will help with appraising the relevant information. There are three main sections to the CASP checklist. The first section is focused on the validity of results. There are six questions used to help the author identify if the results are valid. The second section is focused on what the results are. This helps to determine what each 
study is showing. The third section is focused on how these results can be applied to practice (Critical Appraisal Skills Programme, 2017).

Next, the methods will be discussed. 


\section{Purpose}

\section{Method}

This systematic review examined the efficacy of haloperidol in prophylactically treating postoperative nausea and vomiting in patients who have undergone a laparoscopic surgery under general anesthesia.

\section{Inclusion/Exclusion Criteria}

The inclusion criteria for this systematic review were randomized control trials, subjects over 18 years old and must have had a laparoscopic surgical procedure with general anesthetic; haloperidol must have been used prophylactically for PONV, with the article written in English, and under 10 years old. The study must have included data on the incidence of PONV for 24 hours postoperatively.

The exclusion criteria included articles not written in English, over 10 years old, participants less than 18 years old, not randomized control trials, studies that did include laparoscopic surgical procedures and studies that do not measure incidence of PONV for 24 hours postoperatively.

\section{Search Strategy}

To gather the research that is available, a detailed search included the databases PubMed, CINAHL, and Medline. The search words used were Haldol or haloperidol, postoperative nausea and vomiting, and laparoscopic surgery. The target studies were articles in English that were randomized control trials. The PRISMA flowchart was used to select articles that would be evaluated in the systematic review. On the following page there is the completed PRISMA four stage flow diagram, Figure 1. This demonstrates the selection process of articles included in the systematic review. 


\section{PRISMA 2009 Flow Diagram}
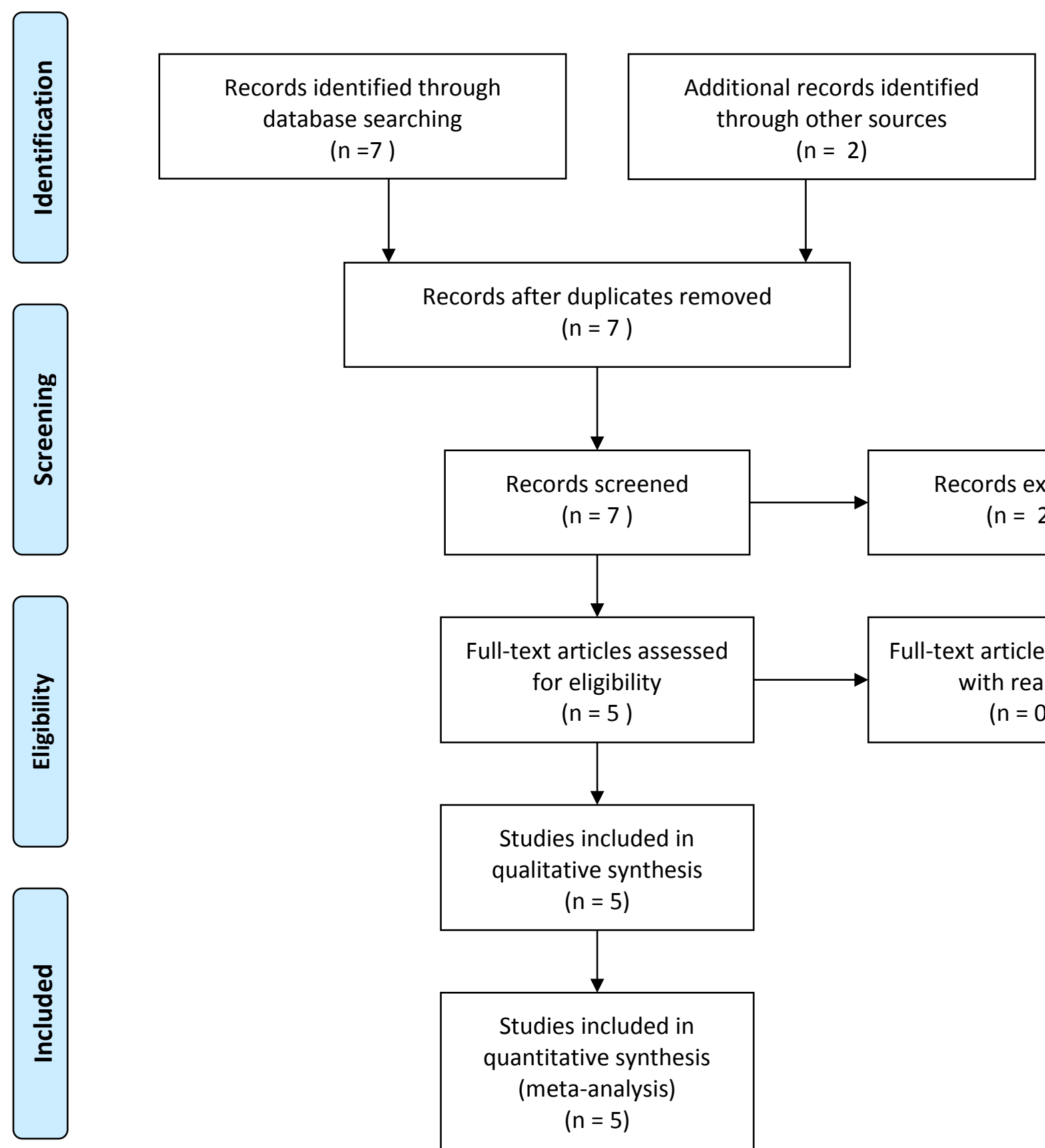

Records after duplicates removed

$$
(n=7)
$$
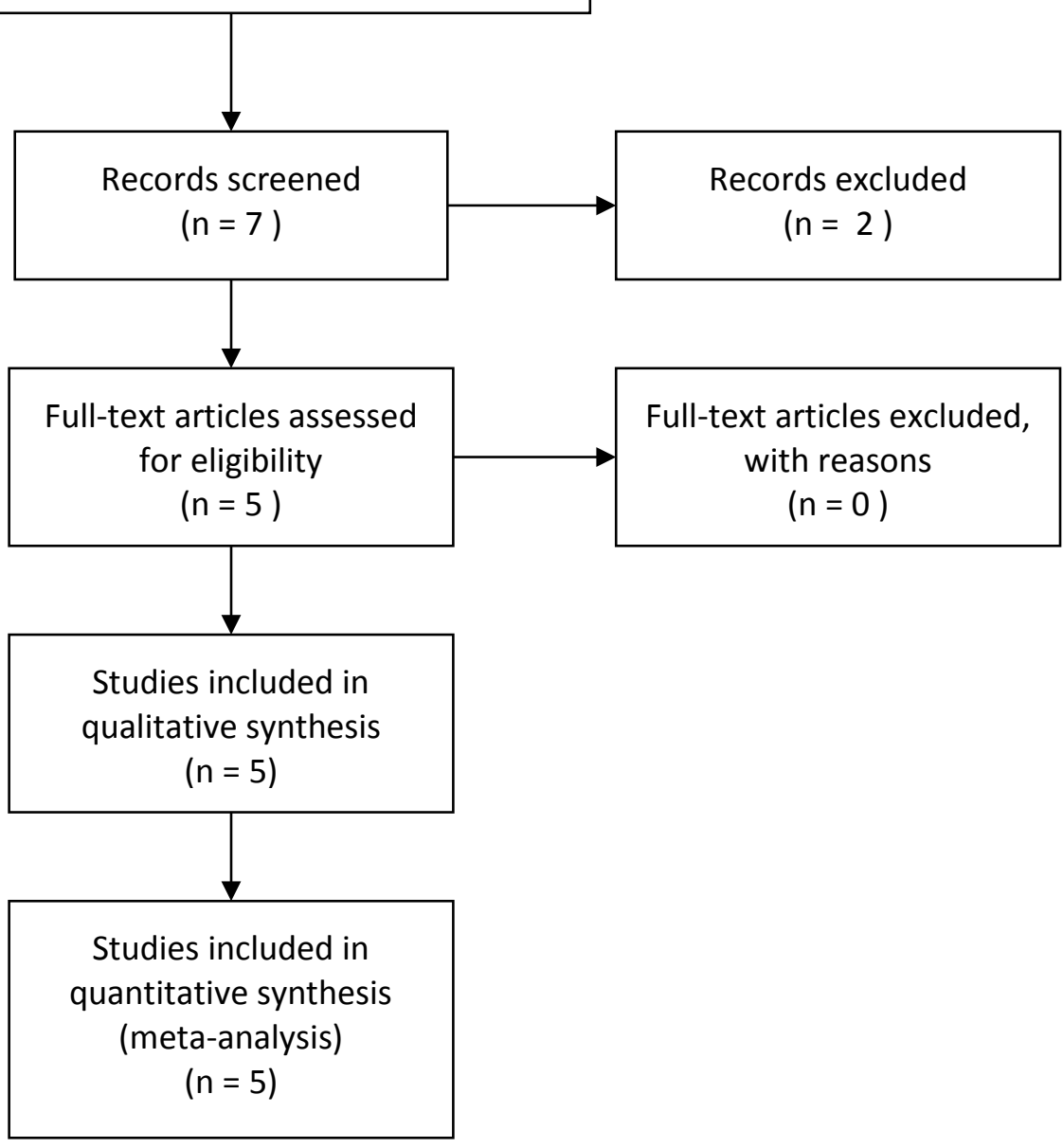

Figure 1. Completed PRISMA Flow Diagram (Moher et al., 2009). 


\section{Data Collection}

Once the articles that were included in the systematic review were selected, each article was reviewed and presented in detailed data collection tables. One table examined the design of the study (Table 1). The other data collection table illustrated the outcomes of each study (Table 2).

Table 1

Study Demographics

Citation

\begin{tabular}{llll}
\hline Purpose & $\underline{\text { Sample }} \quad \underline{\text { Surgical }}$ & Method \\
Procedure &
\end{tabular}

Table 2

Outcomes of the Study

Citation

$\frac{\underline{\text { Nausea and }}}{\underline{\text { Vomiting }}} \quad \underline{\text { Pain Scores }} \quad \underline{\text { Adverse Side }} \quad \underline{\underline{\text { Effects }}}$

The CASP checklist for systematic reviews, illustrated in Table 3 on the next page, was used to critically appraise each article and determined the scientific integrity (Critical Appraisal Skills Programme, 2017). This checklist helped to show how relevant the outcomes were from each study as well as how scientifically strong the evidence was. 
Table 3

CASP Checklist

\begin{tabular}{llll}
\hline A. Are the results of the trial valid? & YES & CAN'T & NO
\end{tabular}

TELL

1. Did the trial address a clearly focused issue?

2. Was the assignment of patients to treatments randomized?

3. Were all of the patients who entered the trial properly accounted for at its conclusion?

4. Were patients, health workers, and study personnel "blind" to treatment?

5. Were the groups similar at the start of the trial?

6. Aside from the experimental intervention, were the groups treated equally?

\section{B. What are the results?}

7. How large was the treatment effect?

8. How precise was the estimate of the treatment effect?

\section{Will the results help locally?}

YES CAN'T NO TELL

9. Can the results be applied in your context?

10. Were all clinically important outcomes considered?

11. Are the benefits worth the harms and costs?

\section{Descriptive Data Analysis}

The data were synthesized into the data collection tables. A final table was created for a cross-study analysis (Table 4). This table combined the information from the different studies and compared the pertinent outcomes from all the studies together. The results from each individual study and the cross-study analysis was then discussed in the results section of the systematic review.

The table used for the cross-study analysis is illustrated in Table 4. 
Table 4

Cross-Study Analysis

\begin{tabular}{|c|c|c|c|}
\hline $\begin{array}{l}\text { Study } \\
\text { number }\end{array}$ & Nausea \& Vomiting & Pain Scores & Side Effects \\
\hline 1 & & & \\
\hline 2 & & & \\
\hline 3 & & & \\
\hline 4 & & & \\
\hline 5 & & & \\
\hline
\end{tabular}

Next, the results will be presented. 


\section{Results}

Five studies met the criteria for this systematic review. All of these studies evaluated how the use of prophylactic haloperidol effected PONV in patients who had undergone laparoscopic surgical procedures. The tables that illustrate the design details of each study can be found in Appendix C, Tables 1-5. Tables that illustrate the results of each study are shown in Appendix D, Tables 1-5. The critical appraisal tables for each study can be found in Appendix E. Appendix F illustrates the cross study analysis.

The study conducted by Benevides, Oliveira and Aguilar-Nscimento (2012) was to evaluate the intensity of nausea, pain and the number of vomiting episodes on postoperative patients who had undergone a laparoscopic sleeve gastrectomy (Appendix C-1). There were 90 patients involved in this double-blind randomized control trial. These patients were divided into three groups. Each group was medicated with a different combination of prophylactic antiemetic medications. Group O received ondansetron only. Group DO received dexamethasone and ondansetron. Group HDO received haloperidol, dexamethasone and ondansetron. Throughout the procedure the anesthetic and surgical techniques were standardized. The postoperative diet was also standardized, advancing based on patients' acceptance. The authors utilized a verbal numeric scale of nausea (VNSN) and a verbal numeric scale of pain (VNSP) to evaluate the patients' pain and nausea. They monitored the number of vomiting or retching episodes.

The results of this study can be seen in Appendix D-1. There was a significant decrease in nausea between Group O and Group HDO ( $=0.001)$, with Group O having a mean intensity score of 4 and group HDO had a score of 1.5. With the episodes of vomiting, the results showed a trend towards statistical significance, with episodes of 
vomiting lower in group HDO than group O (p = 0.052). Group HDO experienced $0.63 \pm$ 1.2 episodes of vomiting compared to group O $1.10 \pm 1.2$, and group DO $0.83 \pm 2$. The pain scores were lower in group HDO than Group O $(p=0.0 .46)$, where the mean intensity score for group O was 2.2 and for Group HDO it was 1 . Some limitations to this study were that there was no control group for this experiment and the sample size was relatively small.

The critical appraisal of this article can be seen in Appendix E-1. This table illustrates that the article did address the focused areas. The assignment of patients was randomized, all patients were accounted for at the end of the study and all personnel who participated in this study were blind to the treatment. All groups were treated equally with the exception of the experimental intervention. The number of patients in the study was relatively small at 90, but the results did show decreased nausea, vomiting and pain scores. Not all clinical outcomes were considered statistically important.

The study by Chu et al., (2008) evaluated the prophylactic effect of haloperidol given alone or in combination with dexamethasone on PONV in patients who underwent a laparoscopic assisted vaginal hysterectomy (Appendix C-2). This was a clinical doubleblind randomized control trial. Four hundred patients were selected for this trial; 28 of the patients were excluded from analysis. The patients were divided into five groups. The first group was Group S, the control group, in which patients were medicated with saline; Group D patients received droperidol; Group H patients received haloperidol; and Group Dx patients received dexamethasone and Group $\mathrm{H}+$ Dx patients received haloperidol and dexamethasone. All patients were medicated with the study drug 15 minutes after the induction of anesthesia. Anesthesia and surgical technique were standardized. The 
authors noted that they used standard monitoring as well as measured the patients' QT intervals. The authors documented PONV by including the incidence of nausea, vomiting, and rescue antiemetics used. Postoperative pain was assessed using a visual analog scale (VAS). Also, any extrapyramidal side effects were noted.

The results are summarized in Appendix D-2. Group S had 49 patients (65\%) who experienced PONV; Group D had 28 patients (36\%); Group H had 27 patients (37\%); Group Dx had 28 patients (38\%); and Group H + Dx had the lowest incidence where 14 patients $(19 \%)$ experienced PONV $(p=0.05)$. There was no statistical difference between Group H, Group Dx and Group D. All of the groups experienced less PONV than Group S. There was no statistical difference in postoperative pain scores between groups. Extrapyramidal side effects were seen in Group D, where two patients experienced motor restlessness and Group H where one patient experienced it. There was no statistical difference between any of the groups. A limitation of this study was that the authors did not utilize a VAS to score patients’ nausea intensity, making the results less sensitive.

The critical appraisal for this study can be found in Appendix E-2. This study was a randomized double-blind trial. All groups were similar in the beginning of this trial and all participants were accounted for at the end. It had a large sample size of 400 people and demonstrated that haloperidol decreased nausea and vomiting. This study did address the focus areas.

Feng et al. (2009) evaluated the prophylactic effect of haloperidol plus ondansetron on PONV with patients undergoing laparoscopic cholecystectomies. The design of this study is summarized in Appendix C-3. This was a clinical double-blind randomized control trial. There were 210 patients to begin this trial, with 18 of them 
excluded. The patients were divided up into three groups. Group H patients were medicated with saline and haloperidol. Group O patient were medicated with ondansetron and saline. Group $\mathrm{H}+\mathrm{O}$ patients were medicated with haloperidol and ondansetron. The anesthesia, mechanical ventilation, and surgical technique were all standardized throughout. Standard monitoring as well as QTc intervals were recorded. All of the patients were monitored for 24 hours postoperatively. The authors recorded the incidence and severity of PONV, the severity of postoperative pain, and the occurrence of adverse side effects.

The results of this study can be seen in Appendix D-3. These authors found that Group $\mathrm{H}+\mathrm{O}$ experienced less PONV than the other groups $(\mathrm{p}<0.05)$. Group H had 25 patients (39\%) experience PONV, Group O had 25 patients (38\%), and Group $\mathrm{H}+\mathrm{O}$ had 13 patients (21\%). The postoperative pain scores were similar in all three groups. Two patients out of the study, one in group $\mathrm{H}$ and one in group $\mathrm{H}+\mathrm{O}$, experienced an adverse side effect of restlessness. A limitation in this study was that there was no true control group.

The critical appraisal for this study is summarized in Appendix E-3. This showed that the study was a double-blinded study that addressed the focus areas. The sample size was 210 people undergoing the same kind of surgery and results demonstrated that haloperidol plus ondansetron decreased nausea and vomiting. The findings can be applied to similar population groups and the benefits were shown to be worth the harms and costs.

Joo et al. (2015) conducted a study (Appendix C-4) that evaluated at which dose haloperidol could be combined with dexamethasone to prevent PONV without adverse 
side effects in patients undergoing gynecological laparoscopic procedures. It was a clinical double-blind randomized trial. There were 150 patients involved in the study. They were divided into three groups with all of the groups were medicated with dexamethasone. Group H0 received saline with the dexamethasone; Group H1 received 1 mg of haloperidol with the dexamethasone; and Group H2 received 2 mg of haloperidol with dexamethasone. Anesthesia, ventilation and surgical technique were all standardized. The authors monitored the incidence of PONV, pain intensity, rescue antiemetics used, and adverse side effects.

Groups H1 and H2 had a significantly lower incidence of PONV than Group H0. In Group H0 21 patients (42\%) experienced PONV; Group H1 11 patients (22\%) experienced it; and Group H2 had 10 patients (20\%) who experienced PONV ( $<<0.017)$. There were no significant differences in pain scores across all three groups. Group H2 did have a significant increase in sedation compared to the other two groups where Group H0 and Group H1 had an average VAS sedation score of 3.5 and Group H2 had an average score of $5(p<0.001)$. There were no cardiac or EPS seen in any of the groups. These results are summarized in Appendix D-4. Some limitations of this study were that there was no real control group since all patients were medicated with dexamethasone. Also, the sample size was relatively small.

The critical appraisal for this study can be seen in Appendix E-4. This was a double-blind randomized study. All groups were similar at the start of the trial and were treated equally with the exception of the experimental intervention. All patients were accounted for at the end of the study. The sample size was smaller, with 150 patients. It did have a precise estimate of the treatment effect showing that haloperidol and 
dexamethasone decreased nausea and vomiting. These results can be applied to similar populations.

The study by Wang et al. (2008) evaluated the prophylactic effect of low-dose haloperidol on post-operative nausea and vomiting in women undergoing ambulatory laparoscopic surgery. The design of this study is summarized in Appendix C-5. It was a randomized double-blind and placebo-controlled study. There was a total of 150 patients in the study, and they were divided into three groups. There was a saline group, which was medicated with saline; a haloperidol group that was medicated with $1 \mathrm{mg}$ of haloperidol; and a droperidol group which was medicated with $0.625 \mathrm{mg}$ of droperidol. The anesthesia and surgical procedures were standardized. The medications were all given 15 minutes after induction of anesthesia. The authors recorded the intensity of the postoperative pain using a VAS scale $0-10$. The incidence of PONV was collected by telephone 24 hours postoperatively. All patients were monitored for any adverse side effects.

The results of this study can be seen in Appendix D-5. The haloperidol and droperidol group both experienced significantly less PONV than the saline group. In the haloperidol group 14 patients (31\%) experienced PONV; the droperidol group had 14 patients (32\%) and the saline group had 29 patients (62\%) who experienced PONV $(p<0.05)$. There were no differences found in postoperative pain scores between the groups. There was no difference in sedation scores and no EPS were noted. A limitation of this study was that since it was done with ambulatory surgery the authors had to rely on getting information over the telephone after the patient was discharged and it was not done under direct observation. 
The critical appraisal table for this study is found in Appendix E-5. This study was a randomized double-blind study. All participants were treated similarly aside from the experimental intervention. It was a relatively small sample size with 150 participants. This study did show a precise treatment effect with decreased nausea and vomiting. The benefits were shown to be worth the harms and costs.

The cross-study analysis can be seen in Appendix F. All five studies showed a statistically significant decrease in PONV when haloperidol was used to prophylactically treat it. Pain scores were not significantly different except for in the study conducted by Benevides et al. (2012), which showed a decrease in pain in the group that was medicated with haloperidol. Benevides et al. did not identify any adverse side effects of haloperidol in their study. The study by Chu et al. (2008) noted two patients who experienced the EPS symptom of motor restlessness; Feng et al. (2009) also noted two patients in their study experienced motor restlessness. In the study by Joo et al. (2015), there were no extrapyramidal side symptoms (EPS) noted; however, in groups medicated with $2 \mathrm{mg}$ of haloperidol there was increased sedation levels. Wang et al. (2008) stated there were no adverse side effects of haloperidol noted. Overall, the studies all concluded that haloperidol can be used safely as a medication to prophylactically treat PONV.

The next section will discuss the summary and conclusions. 


\section{Summary and Conclusions}

Postoperative nausea and vomiting is a continuous problem that affects up to $30 \%$ of all patients undergoing general anesthesia (Pierre \& Whelan, 2013). This complication can increase recovery time and length of stay for the patients. This is very uncomfortable for the patients and has led to decreased satisfaction scores (Flood et al., 2015). It can also be dangerous for the patient putting them at risk for wound dehiscence and aspiration (Nagelhout \& Plaus, 2014). There are many identified risk factors for PONV. The patient specific risk factors are female gender, age less than 50, nonsmokers and a history of PONV or motion sickness (Nagelhout \& Plaus). Patients who are at determined to be at high risk for PONV have an 80\% chance of experiencing it (Pierre \& Whelan, 2013). This is why it is so important to prevent a patient from experiencing this complication. Currently, a prophylactic approach to preventing PONV is being used. The vomiting center of the brain can be found in the NTS and there are several different neurotransmitters that control the activity in the vomiting center. There is also the chemoreceptor trigger zone which detects noxious chemicals (Flood et al., 2015). Because PONV can be triggered so many different ways, there are a number of ways that we can prevent it. It has been shown that many medications can prevent PONV by working on different receptor sites, but that when they are used in combination with each other they can have an additive effect (Pierre \& Whelan, 2013). One medication that is being used to prophylactically treat PONV is haloperidol. This medication is an antagonist of the D2 dopamine receptor, preventing PONV at the vomiting center (Flood et al.). 
This systematic review evaluated randomized control trials that examined how haloperidol worked as a prophylactic agent of PONV. The PRISMA framework was used as a theoretical framework to guide the selection of the articles used in the systematic review. CASP was used to critically appraise each study. PubMed, CINAHL, and Medline were searched for haloperidol, postoperative nausea and vomiting, and laparoscopic surgery. Once the inclusion and exclusion criteria were applied, there were five articles that were included in this systematic review. Each study was evaluated and data were collected in two tables and the CASP table.

The main findings of this systematic review showed that haloperidol was successful in reducing PONV. Every study showed that this medication can significantly reduce the number of vomiting episodes and accounts of nausea reported. Some of the articles discussed the side effects of haloperidol, and the occurrence of these was not found to be statistically significant. Over all, the studies showed that using haloperidol in a multimodal approach to prevent PONV was even more successful than using one medication alone.

These findings can be directly applied to similar populations of patients undergoing general anesthesia and directly answers the focus problem. There are some limitations to this systematic review. There was a limited number of studies included in this systematic review. Also, most of the studies that were included had a limited sample.

In conclusion, this systematic review supports the use of haloperidol as a medication to be used in preventing PONV. The studies found haloperidol works better when being used in a multimodal approach with other prophylactic medications for PONV. The next section of this paper will discuss the implications in nursing practice. 


\section{Recommendations and Implications for Advanced Nursing Practice}

This systematic review yielded information that can be utilized specifically in advanced nursing practice. Postoperative nausea and vomiting is a problem that every anesthesia provider must consider when administering general anesthesia. Part of the nurse anesthetist role as an advanced provider is to make critical thinking decisions and provide the best possible care to each patient. Prophylactically treating a patient with a multimodal approach the incidence of PONV can be greatly decreased. The multimodal approach should be implanted in anesthesia provider practice to provide better patient outcomes.

For an anesthesia provider to utilize haloperidol as one medication in a prophylactic approach, they need to understand the mechanism of action, efficacy and possible side effects. Providers should also understand the pathophysiology of PONV and the risk factors so that they can identify patients that are more likely to suffer from PONV. Educating anesthesia providers on PONV, a prophylactic multimodal approach to prevent PONV, and specific medications such as haloperidol is needed.

CRNA's can be instrumental in developing and implementing evidence-based guidelines to prevent PONV. Utilizing a risk scoring system, such as the Apfel risk score, to identify patients at high risk of PONV should be a standardized practice since patients at high risk of PONV have an incidence of up to $80 \%$. Guidelines should discuss a prophylactic approach with two or more medications for these patients and haloperidol should be one of the standardized options. Every medication choice must be patient specific but having guidelines and options can help educated practitioners make the best decisions. 
Further research is needed on this topic. There are many medications that can be utilized for prevention of PONV, with new ones being developed. Studies to determine how effective and safe each of these medications are should be routinely performed. Also, this systematic review specifically evaluated studies that involved laparoscopic surgical procedures yet PONV is a possible complication of all general surgeries. The efficacy of haloperidol and other antiemetic medications should be studied on all kinds of general surgery. 


\section{References}

Akkurt, B., Temiz, M., Inanoglu, K., Aslan, A., Turhanoglu, S., Asfuroglu, Z., \& Canbolant, E.. (2009). Comparison of recovery characterisitics, postoperative nausea and vomiting, and gastrointestinal motility with total intravenous anesthesia with propofol versus inhalation anesthesia with desflurane for laparoscopic cholecystectomy: A randomized controlled study. Current Therapeutic Research, Clinical and Experimental, 70(2), 94-103.

Aouad, M., Siddik-Sayyid, S., Taha, S., Azar, M., Nasr, V., Hakki, M. ... \& Baraka, A.. (2007). Haloperidol vs. ondansetron for the prevention of postoperative nausea and vomiting following gynaecological surgery. European Journal of Anesthesiology, 24(2), 171-178.

Benevidea, M., Oliveira, S., \& Aguilar-Nascimento, J.. (2012). Combination of haloperidol, dexamethasone, and ondansetron reduces nausea and pain intensity and morphine consumption after laparoscopic sleeve gastrectomy. Revista Brasileria de Anestesiologia, 63(5), 404-409.

Biswas, B. \& Rudra, A.. (2003). Comparison of granisetron and granisetron plus dexamethasone for the prevention of postoperative nausea and vomiting after laparoscopic cholecystectomy. Acta Anaesthesiologica Scandinavica, 47, 79-83. doi:10.1034/j.1399-6576.2003.470114.X

Butterworth, Mackey \& Wasnick. (2013). Morgan and Mikhail’s clinical anesthesiology. New York: McGraw-Hill.

Buttner, M., Walder, B., Elm, E., \& Tramer, M. (2004). Is low-dose haloperidol a useful antiemetic. Anesthesiology, 101, 1454-1463. 
Chamberlain, R., \& Sakpal, S. (2009). A comprehensive review of single-incision laparoscopic surgery and natural orifice transluminal endoscopic surgery techniques for cholecystectomy. Journal of Gastrointestinal Surgery, 13(9), 17331740.

Chatterjee, S., Rudra, A., \& Sengupta, S. (2011). Current concepts in the management of postoperative nausea and vomiting. Anesthesiology Research and Practice, 2011, $1-10$.

Chu, C., Shieh, J., Tzeng, J., Chen, J., Lee, Y., Ho, S., \& Wang, J.. (2008). The prophylactic effect of haloperidol plus dexamethasone on postoperative nausea and vomiting in patients undergoing laparoscopic assisted vaginal hysterectomy. Ambulatory Anesthesiology, 106(5), 1402-1406.

Critical Appraisal Skills Programme. (2017). CASP systematic reviews checklist. Retrieved from http://docs.wixstatic.com/ugd/dded87_7e983a320087439e94533f4697aa109c.pdf

Feng, P., Chu, K., Lu, I., Shieh, J., Tzeng, J., Ho, S., Wang, J., \& Chu, C. (2009). Haloperidol plus ondansetron prevents postopertative nausea and vomiting in patients undergoing laparoscopic cholecystectomy. Taiwan Society of Anesthesiologists, 47(1), 3-9.

Flood. P., Rathmell, J., Shafer, S.. (2015). Stoelting's pharmacology \& physiology in anesthetic practice ( th $^{\text {th }}$ ed.). Philadelphia: Wolters Kluwer.

Gan, T., Diemunsch, P., Habib, A., Kovac, A., Kranke, P., Meyer, T. ... Tramer, M.. (2014). Consensus guidelines for the management of postoperative nausea and vomiting. Society for Ambulatory Anesthesiology, 118, 85-113. 
Joo, J., Park, Y., Baek, J., \& Moon, Y. (2015). Haloperidol dose combined with dexamethasone for PONV prophylaxis in high-risk patients undergoing gynecological laparoscopic surgery: a prospective, randomized, double-blind, dose response and placebo controlled study. BMC Anesthesiology, 15, 1-6

LiveStrong. (2015). Complications after laparoscopic surgery. Retrieved from http://www.livestrong.com/article/234791-complications-after-laparoscopicsurgery/

Moher, D., Liberati, A., Tetzlaff, J., \& Altman, D. (2009). Preferred reporting items for systematic reviews and meta-analyses: The PRISMA statement. PLoS Medicine, 6(7), 1-6. doi:10.1371/journal.pmed.1000097

Nagelhout, J. J., \& Plaus, K. L. (2014). Nurse anesthesia (5th ed.). St. Louis, Missouri: Elsevier Saunders.

Pierre, S., Benais, H., \& Pouymayou, J.. (2002). Apfel’s simplified score may favourable predict the risk of postoperative nausea and vomiting. Canadian Journal of Anesthesia, 49(3), 237-242.

Pierre, S. \& Whelan, R. (2013). Nausea and vomiting after surgery. BJA Education, 13(1), 28-31.

PRISMA Transparent Reporting of Systematic Reviews and Meta-Analyses. (2015). PRISMA statement. Retrieved from http://www.prismastatement.org/PRISMAStatement/PRISMAStatement.aspx

Rusch, D., Eberhart, L., Wallenborn, J., \& Kranke, P. (2010). Nausea and vomiting after surgery under general anesthesia: An evidence-based review concerning risk 
assessment, prevention, and treatment. Deutsches Arzteblatt International, 107(42), 733-741.

Smith, H., Smith, E., \& Smith, B. (2012). Postoperative nausea and vomiting. Annals of Palliative Medicine, 1(2). DOI: 10.3978/j.issn.2224-5820.2012.07.05

Wang, T., Liu, Y., Chu, C., Shieh, J., Tzeng, J., \& Wang, J. (2008) Low-dose haloperidol prevents postoperative nausea and vomiting after ambulatory laparoscopic surgery. Acta Anaesthesiologica Scandinavica, 52, 280-284.

Wolf, R., Morinello, E., Kestler, G., Kasmann-Kellner, B., Bischoff, M., Hager, T.... \& Eberhart, L. (2016). PONV after strabismus surgery: Risk adapted prophylaxis. Anaesthesist, 66(7), 507-513. 
Appendix A

PRISMA 2009 Flow Diagram
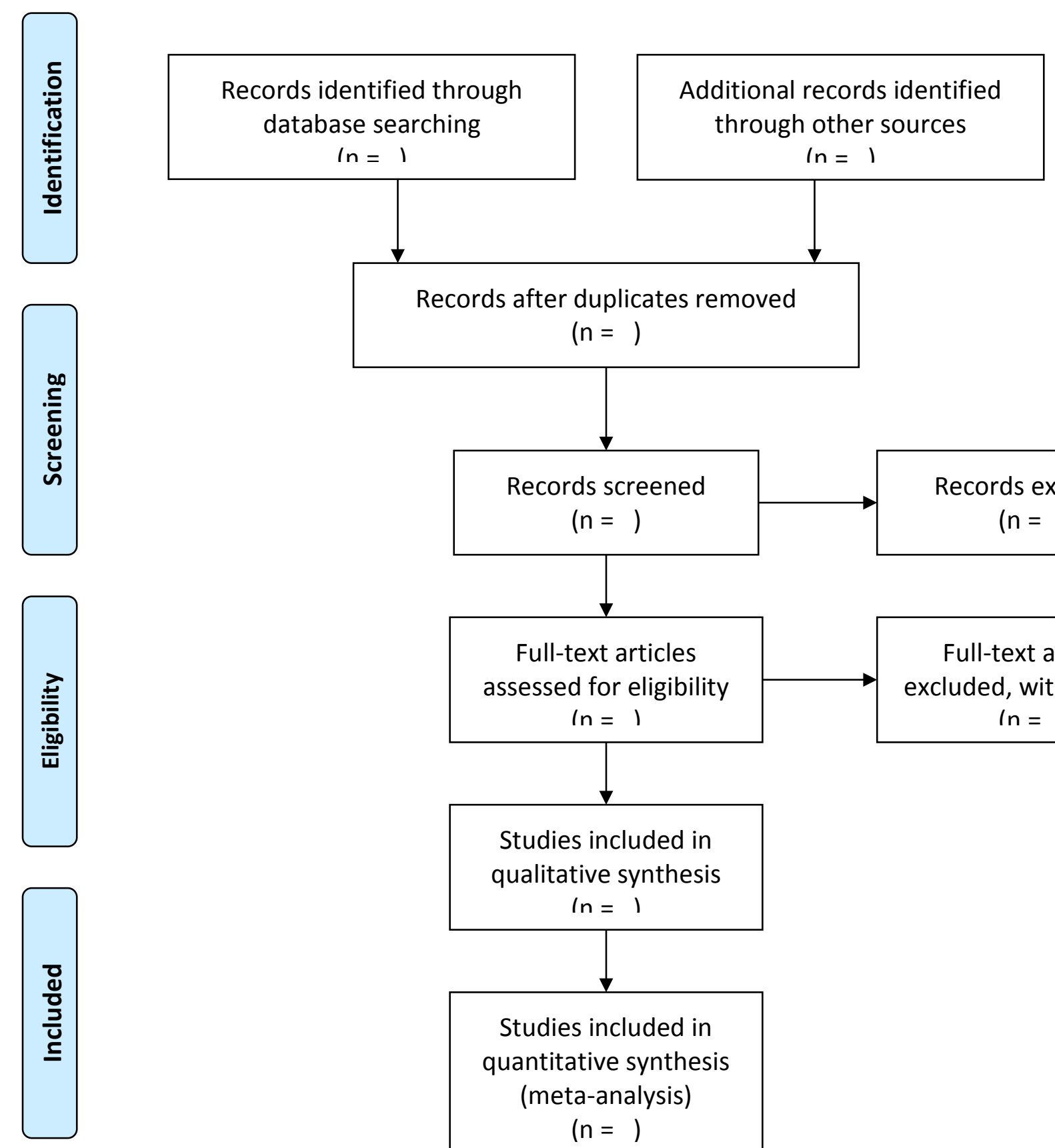

Records after duplicates removed

$$
(n=)
$$

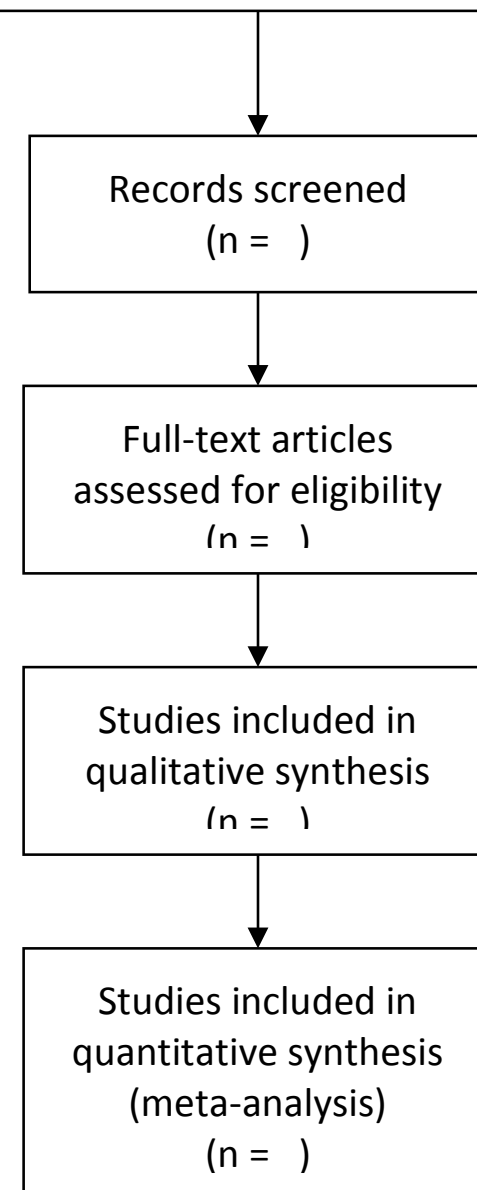

(PRISMA Transparent Reporting of Systematic Reviews and Meta-Analyses, 2015) 


\section{Appendix B}

\begin{tabular}{|c|c|c|c|}
\hline Section/topic & $\#$ & Checklist item & $\begin{array}{l}\text { Reported } \\
\text { on page \# }\end{array}$ \\
\hline \multicolumn{4}{|l|}{ TITLE } \\
\hline Title & 1 & Identify the report as a systematic review, meta-analysis, or both. & \\
\hline \multicolumn{4}{|l|}{ ABSTRACT } \\
\hline $\begin{array}{l}\text { Structured } \\
\text { summary }\end{array}$ & 2 & $\begin{array}{l}\text { Provide a structured summary including, as applicable: background; objectives; data sources; study eligibility } \\
\text { criteria, participants, and interventions; study appraisal and synthesis methods; results; limitations; conclusions } \\
\text { and implications of key findings; systematic review registration number. }\end{array}$ & \\
\hline \multicolumn{4}{|l|}{ INTRODUCTION } \\
\hline Rationale & 3 & Describe the rationale for the review in the context of what is already known. & \\
\hline Objectives & 4 & $\begin{array}{l}\text { Provide an explicit statement of questions being addressed with reference to participants, interventions, } \\
\text { comparisons, outcomes, and study design (PICOS). }\end{array}$ & \\
\hline \multicolumn{4}{|l|}{ METHODS } \\
\hline $\begin{array}{l}\text { Protocol and } \\
\text { registration }\end{array}$ & 5 & $\begin{array}{l}\text { Indicate if a review protocol exists, if and where it can be accessed (e.g., Web address), and, if available, provide } \\
\text { registration information including registration number. }\end{array}$ & \\
\hline Eligibility criteria & 6 & $\begin{array}{l}\text { Specify study characteristics (e.g., PICOS, length of follow-up) and report characteristics (e.g., years considered, } \\
\text { language, publication status) used as criteria for eligibility, giving rationale. }\end{array}$ & \\
\hline $\begin{array}{l}\text { Information } \\
\text { sources }\end{array}$ & 7 & $\begin{array}{l}\text { Describe all information sources (e.g., databases with dates of coverage, contact with study authors to identify } \\
\text { additional studies) in the search and date last searched. }\end{array}$ & \\
\hline Search & 8 & $\begin{array}{l}\text { Present full electronic search strategy for at least one database, including any limits used, such that it could be } \\
\text { repeated. }\end{array}$ & \\
\hline Study selection & 9 & $\begin{array}{l}\text { State the process for selecting studies (i.e., screening, eligibility, included in systematic review, and, if applicable, } \\
\text { included in the meta-analysis). }\end{array}$ & \\
\hline $\begin{array}{l}\text { Data collection } \\
\text { process }\end{array}$ & 10 & $\begin{array}{l}\text { Describe method of data extraction from reports (e.g., piloted forms, independently, in duplicate) and any } \\
\text { processes for obtaining and confirming data from investigators. }\end{array}$ & \\
\hline Data items & 11 & $\begin{array}{l}\text { List and define all variables for which data were sought (e.g., PICOS, funding sources) and any assumptions and } \\
\text { simplifications made. }\end{array}$ & \\
\hline $\begin{array}{l}\text { Risk of bias in } \\
\text { individual studies }\end{array}$ & 12 & $\begin{array}{l}\text { Describe methods used for assessing risk of bias of individual studies (including specification of whether this was } \\
\text { done at the study or outcome level), and how this information is to be used in any data synthesis. }\end{array}$ & \\
\hline $\begin{array}{l}\text { Summary } \\
\text { measures }\end{array}$ & 13 & State the principal summary measures (e.g., risk ratio, difference in means). & \\
\hline $\begin{array}{l}\text { Synthesis of } \\
\text { results }\end{array}$ & 14 & $\begin{array}{l}\text { Describe the methods of handling data and combining results of studies, if done, including measures of } \\
\text { consistency }\left(\mathrm{e} . \mathrm{g} ., \mathrm{I}^{2}\right) \text { for each meta-analysis. }\end{array}$ & \\
\hline $\begin{array}{l}\text { Risk of bias } \\
\text { across studies }\end{array}$ & 15 & $\begin{array}{l}\text { Specify any assessment of risk of bias that may affect the cumulative evidence (e.g., publication bias, selective } \\
\text { reporting within studies). }\end{array}$ & \\
\hline $\begin{array}{l}\text { Additional } \\
\text { analyses }\end{array}$ & 16 & $\begin{array}{l}\text { Describe methods of additional analyses (e.g., sensitivity or subgroup analyses, meta-regression), if done, } \\
\text { indicating which were pre-specified. }\end{array}$ & \\
\hline \multicolumn{4}{|l|}{ RESULTS } \\
\hline Study selection & 17 & $\begin{array}{l}\text { Give numbers of studies screened, assessed for eligibility, and included in the review, with reasons for exclusions } \\
\text { at each stage, ideally with a flow diagram. }\end{array}$ & \\
\hline $\begin{array}{l}\text { Study } \\
\text { characteristics }\end{array}$ & 18 & $\begin{array}{l}\text { For each study, present characteristics for which data were extracted (e.g., study size, PICOS, follow-up period) } \\
\text { and provide the citations. }\end{array}$ & \\
\hline $\begin{array}{l}\text { Risk of bias } \\
\text { within studies }\end{array}$ & 19 & Present data on risk of bias of each study and, if available, any outcome level assessment (see item 12). & \\
\hline $\begin{array}{l}\text { Results of } \\
\text { individual studies }\end{array}$ & 20 & $\begin{array}{l}\text { For all outcomes considered (benefits or harms), present, for each study: (a) simple summary data for each } \\
\text { intervention group (b) effect estimates and confidence intervals, ideally with a forest plot. }\end{array}$ & \\
\hline $\begin{array}{l}\text { Synthesis of } \\
\text { results }\end{array}$ & 21 & Present results of each meta-analysis done, including confidence intervals and measures of consistency. & \\
\hline $\begin{array}{l}\text { Risk of bias } \\
\text { across studies }\end{array}$ & 22 & Present results of any assessment of risk of bias across studies (see Item 15). & \\
\hline $\begin{array}{l}\text { Additional } \\
\text { analysis }\end{array}$ & 23 & $\begin{array}{l}\text { Give results of additional analyses, if done (e.g., sensitivity or subgroup analyses, meta-regression [see Item } \\
\text { 16]). }\end{array}$ & \\
\hline \multicolumn{4}{|l|}{ DISCUSSION } \\
\hline $\begin{array}{l}\text { Summary of } \\
\text { evidence }\end{array}$ & 24 & $\begin{array}{l}\text { Summarize the main findings including the strength of evidence for each main outcome; consider their relevance } \\
\text { to key groups (e.g., healthcare providers, users, and policy makers). }\end{array}$ & \\
\hline Limitations & 25 & $\begin{array}{l}\text { Discuss limitations at study and outcome level (e.g., risk of bias), and at review-level (e.g., incomplete retrieval of } \\
\text { identified research, reporting bias). }\end{array}$ & \\
\hline Conclusions & 26 & $\begin{array}{l}\text { Provide a general interpretation of the results in the context of other evidence, and implications for future } \\
\text { research. }\end{array}$ & \\
\hline \multicolumn{4}{|l|}{ FUNDING } \\
\hline Funding & 27 & $\begin{array}{l}\text { Describe sources of funding for the systematic review and other support (e.g., supply of data); role of funders for } \\
\text { the systematic review. }\end{array}$ & \\
\hline
\end{tabular}


(PRISMA Transparent Reporting of Systematic Reviews and Meta-Analyses, 2015). 


\section{Appendix C}

\begin{tabular}{|c|c|c|c|c|}
\hline \multicolumn{5}{|c|}{$\begin{array}{l}\text { C-1: Benevides, M. L., Oliveira, S., \& Aguilar-Nascimento, J. E., (2012). Combination of haloperidol, } \\
\text { dexamethasone, and ondansetron reduces nausea and pain intensity and morphine consumption after laparoscopic } \\
\text { sleeve gastrectomy. Revista Brasileira De Anestesiologia, 63(5), 404-409. }\end{array}$} \\
\hline Purpose & $\underline{\text { Design }}$ & $\underline{\text { Sample }}$ & $\underline{\text { Surgical Procedure }}$ & Method \\
\hline $\begin{array}{l}\text { To evaluate the } \\
\text { intensity of nausea } \\
\text { and pain and the } \\
\text { number of } \\
\text { vomiting episodes } \\
\text { in postoperative } \\
\text { patients. }\end{array}$ & $\begin{array}{l}\text { A clinical double- } \\
\text { blind randomized } \\
\text { control trial with } \\
\text { three groups, each } \\
\text { with } 30 \text { patients. } \\
\text { Group O received } \\
\text { ondansetron only; } \\
\text { Group DO } \\
\text { received } \\
\text { dexamethasone } \\
\text { and ondansetron; } \\
\text { Group HDO } \\
\text { received } \\
\text { haloperidol, } \\
\text { dexamethasone, } \\
\text { and ondansetron }\end{array}$ & $\begin{array}{l}90 \text { Patients were } \\
\text { included in total. } \\
\text { They were all } \\
\text { greater than } 18 \\
\text { years old, a mix of } \\
\text { males and females } \\
\text { and BMI > 35. } \\
\text { ASA levels I - III } \\
\text { were included. }\end{array}$ & $\begin{array}{l}\text { Laparoscopic } \\
\text { sleeve } \\
\text { gastrectomy. }\end{array}$ & $\begin{array}{l}\text { Anesthetic technique was } \\
\text { standardized with induction } \\
\text { and maintenance medications } \\
\text { based on ideal body weight. } \\
\text { Surgical technique was } \\
\text { standardized. } \\
\text { Postoperative diet was } \\
\text { standardized based on patient’s } \\
\text { acceptance. } \\
\text { The Verbal numeric scale of } \\
\text { nausea (VNSN) and the verbal } \\
\text { numeric scale of pain (VNSP) } \\
\text { were utilized to evaluate } \\
\text { nausea and pain. } \\
\text { Nausea and pain were } \\
\text { evaluated 2, 12, 24, and } 36 \\
\text { hours postoperatively. }\end{array}$ \\
\hline
\end{tabular}




\begin{tabular}{|c|c|c|c|c|}
\hline \multicolumn{5}{|c|}{$\begin{array}{l}\text { C-2: Chu, C., Shieh, J., Tzeng, J., Chen, J., Lee, Y., Ho, S., \& Wang, J. (2008). The prophylactic effect of haloperidol plus } \\
\text { dexamethasone on postoperative nausea and vomiting in patients undergoing laparoscoically assisted vaginal } \\
\text { hysterectomy. Ambulatory Anesthesiology, 106(5), 1402-1406. }\end{array}$} \\
\hline Purpose & Design & Sample & Surgical Procedure & Method \\
\hline $\begin{array}{l}\text { To evaluate the } \\
\text { prophylactic effect } \\
\text { of haloperidol } \\
\text { given alone or in } \\
\text { combination with } \\
\text { dexamethasone on } \\
\text { PONV. }\end{array}$ & $\begin{array}{l}\text { A clinical double- } \\
\text { blind randomized } \\
\text { control trial with a } \\
\text { control group. } \\
\text { There were five } \\
\text { groups, each with } \\
80 \text { patients. Group } \\
\text { S received a } \\
\text { placebo. Group D } \\
\text { received } \\
\text { droperidol. Group } \\
\text { H received } \\
\text { haloperidol. Group } \\
\text { Dx received } \\
\text { dexamethasone. } \\
\text { And Group H + } \\
\text { Dx received } \\
\text { haloperidol and } \\
\text { dexamethasone. }\end{array}$ & $\begin{array}{l}\text { A total of } 400 \\
\text { patients, all } \\
\text { women. All } \\
\text { patients were ASA } \\
\text { level I or II. } \\
\text { Exclusion criteria } \\
\text { included difficult } \\
\text { airway, obesity, } \\
\text { pregnancy, } \\
\text { psychiatric illness, } \\
\text { major organ } \\
\text { disease. } 28 \text { of the } \\
400 \text { patients } \\
\text { enrolled were } \\
\text { excluded from the } \\
\text { analysis. }\end{array}$ & $\begin{array}{l}\text { Laparoscopic- } \\
\text { assisted vaginal } \\
\text { hysterectomy. }\end{array}$ & $\begin{array}{l}\text { Patients were medicated } 15 \text { minutes } \\
\text { after the induction of anesthesia. } \\
\text { Anesthesia was standardized for all } \\
\text { patients. Ventilation was controlled } \\
\text { mechanically and adjusted to } \\
\text { maintain end-tidal carbon dioxide. } \\
\text { Standard monitoring was used and } \\
\text { QT intervals were measured. } \\
\text { Patients were observed } \\
\text { postoperatively for } 24 \text { hours. The } \\
\text { incidence and severity of PONV } \\
\text { were documented including the } \\
\text { incidence of nausea, vomiting, } \\
\text { nausea and vomiting, and rescue } \\
\text { antiemetics used. Postoperative pain } \\
\text { was assessed } 24 \text { hours } \\
\text { postoperatively using the visual } \\
\text { analog scale (VAS). All } \\
\text { extrapyramidal side effects noted in a } \\
24 \text { hour period were documented. }\end{array}$ \\
\hline
\end{tabular}




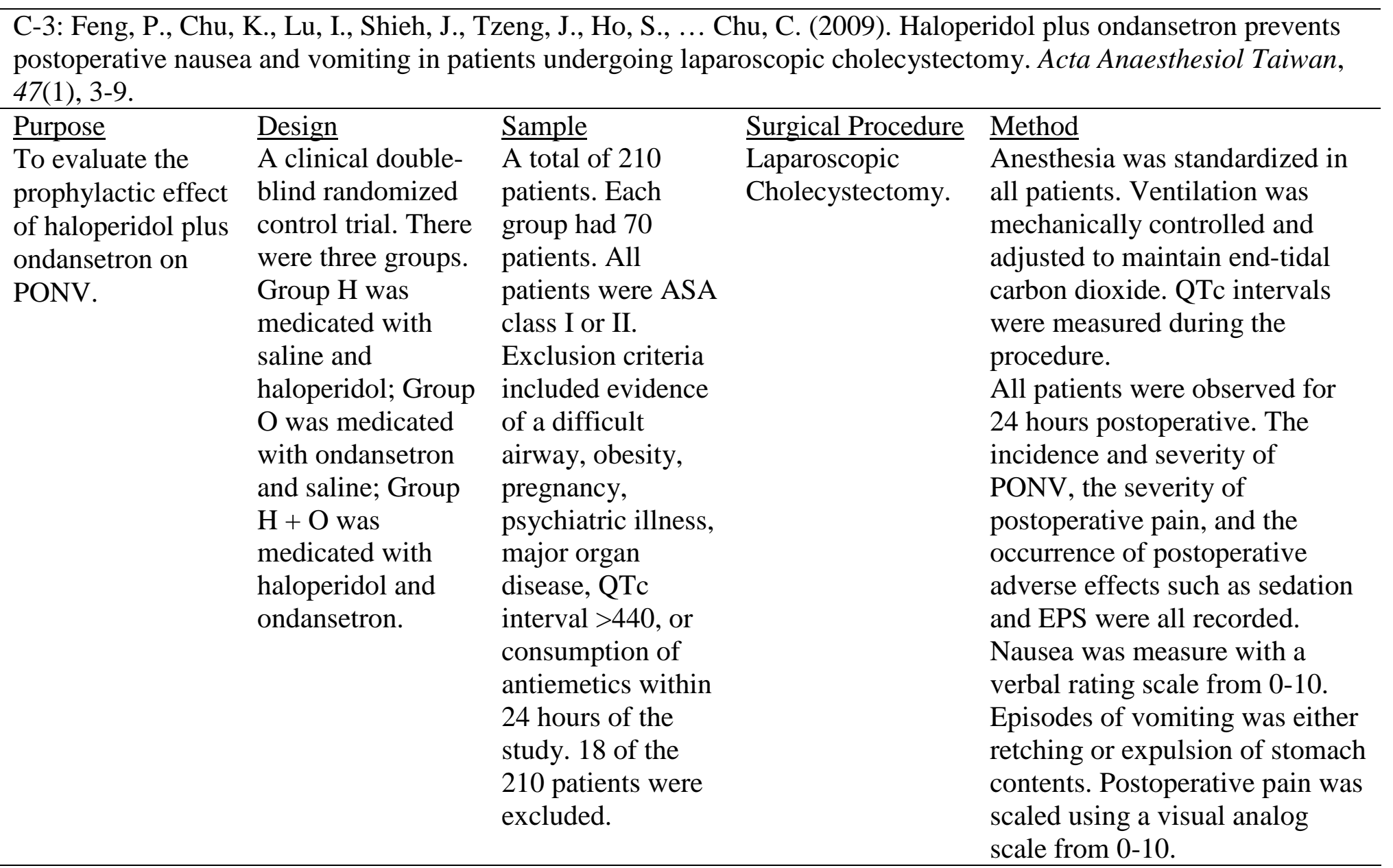


C-4: Joo, J., Park, Y., Baek, J., \& Moon, Y. (2015). Haloperidol dose combined with dexamethasone for ponv prophylaxis in high-risk patients undergoing a gynecological laparoscopic surgery: a prospective, randomized, doubleblind, dose-response and placebo-controlled study. BMC Anesthesiology, 15(99), 1-6.

\begin{tabular}{|c|c|c|c|c|}
\hline Purpose & Design & Sample & $\underline{\text { Surgical Procedure }}$ & Method \\
\hline $\begin{array}{l}\text { To identify which } \\
\text { dose of } \\
\text { haloperidol could } \\
\text { be combined with } \\
\text { dexamethasone } \\
\text { without adverse } \\
\text { effects to prevent } \\
\text { PONV in high-risk } \\
\text { patients. }\end{array}$ & $\begin{array}{l}\text { A clinical double- } \\
\text { blind randomized } \\
\text { control trial with a } \\
\text { control group. } \\
\text { Patients were } \\
\text { divided up into } \\
\text { three groups. All } \\
\text { of the groups were } \\
\text { medicated with } \\
\text { dexamethasone. } \\
\text { Group H0 was } \\
\text { medicated with } \\
\text { saline; Group H1 } \\
\text { medicated with } 1 \\
\text { mg of haloperidol; } \\
\text { Group H2 was } \\
\text { medicated with } 2 \\
\text { mg haloperidol. }\end{array}$ & $\begin{array}{l}\text { There was a total } \\
\text { of } 150 \text { female } \\
\text { adult patients } \\
\text { involved in this } \\
\text { study. They were } \\
\text { all ASA class I or } \\
\text { II, ages between } \\
\text { 20-65. All patients } \\
\text { were non-smokers } \\
\text { and used opioids } \\
\text { for postoperative } \\
\text { pain control. One } \\
\text { patient was } \\
\text { excluded due to } \\
\text { intraoperative } \\
\text { conversion to an } \\
\text { open laparotomy. }\end{array}$ & $\begin{array}{l}\text { Gynecological } \\
\text { laparoscopic } \\
\text { surgeries. }\end{array}$ & $\begin{array}{l}\text { Anesthesia was standardized, } \\
\text { titrated to maintain a BIS value of } \\
\text { 40-60. All patients received } 5 \text { mg } \\
\text { dexamethasone IV during } \\
\text { induction. Ventilation was } \\
\text { controlled mechanically and } \\
\text { adjusted to maintain end-tidal } \\
\text { carbon dioxide 30-40. Haloperidol } \\
\text { was administered approximately } \\
30 \text { min before the end of } \\
\text { anesthesia. All patients were given } \\
\text { a PCA for postoperative pain } \\
\text { control. } \\
\text { The authors monitored the } \\
\text { incidence of postoperative nausea } \\
\text { and vomiting, pain intensity, } \\
\text { rescue antiemetics used, and } \\
\text { adverse side effects. Nausea was } \\
\text { graded as tolerable or intolerable. } \\
\text { Postoperative pain was measured } \\
\text { using a visual analogue scale from } \\
0 \text {-10. Sedation was assessed on a } \\
\text { VAS scale 0-10. }\end{array}$ \\
\hline
\end{tabular}




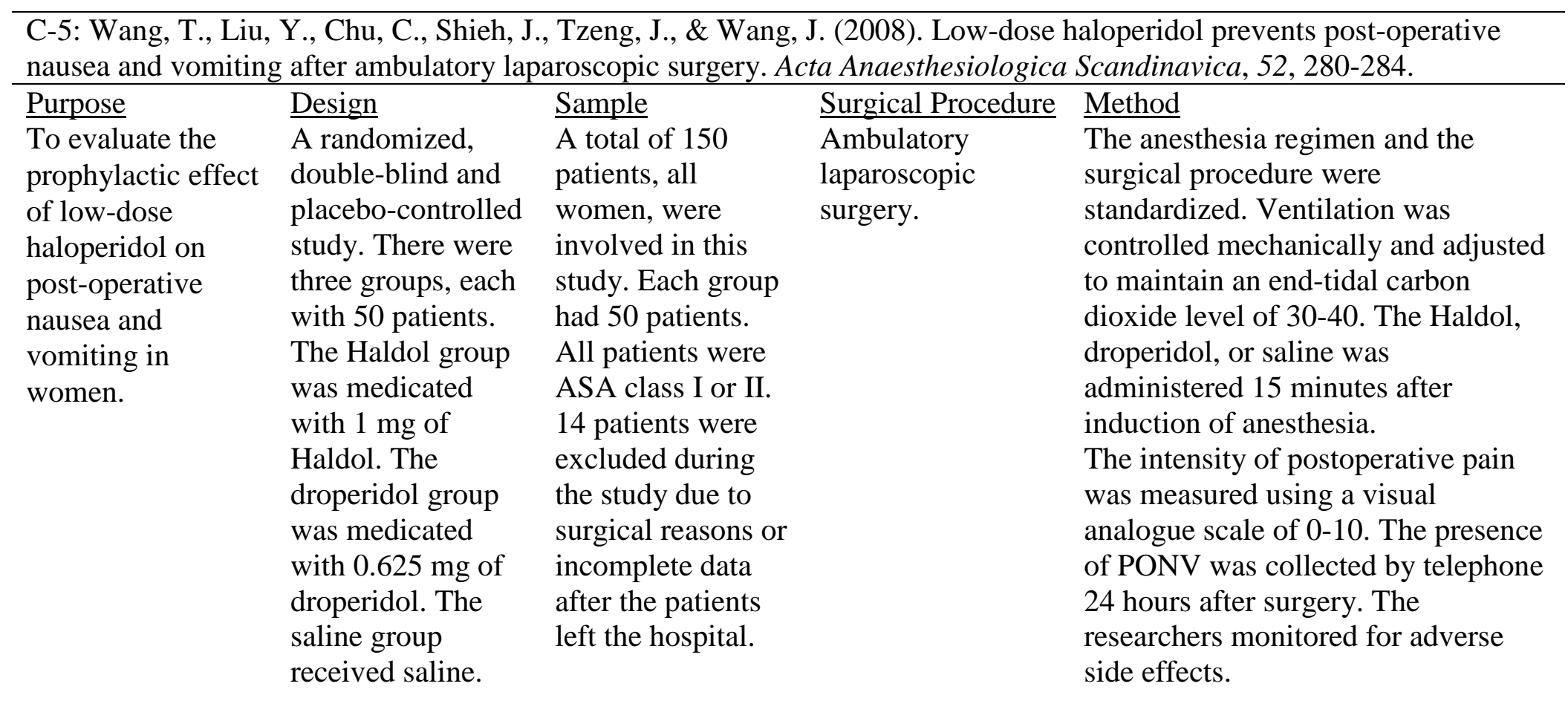




\section{Appendix D}

D-1: Benevides, M. L., Oliveira, S., \& Aguilar-Nascimento, J. E., (2012). Combination of haloperidol, dexamethasone, and ondansetron reduces nausea and pain intensity and morphine consumption after laparoscopic sleeve gastrectomy. Revista Brasileira De Anestesiologia, 63(5), 404-409.

Nausea and Vomiting

The mean intensity of nausea through the VNSN for Group O was 4; Group DO it was

2.1; Group HDO it was 1.5 $(\mathrm{p}=0.001)$.

Group HDO experienced

$0.63 \pm 1.2$ episodes of vomiting compared to group O $1.10 \pm 1.2$, and group DO

$0.83 \pm 2(\mathrm{p}=0.052)$.

\section{$\underline{\text { Pain Scores }}$}

The mean intensity of pain through the VNSP for group O was 2.2; Group DO it was 1.9; Group HDO it was 1 (p $=0.046$ ).

\section{$\underline{\text { Adverse Side Effects }}$}

This study did not monitor for adverse side effects.

\section{Limitations}

There was not a control group for this experiment. 
D-2: Chu, C., Shieh, J., Tzeng, J., Chen, J., Lee, Y., Ho, S., \& Wang, J. (2008). The prophylactic effect of haloperidol plus dexamethasone on postoperative nausea and vomiting in patients undergoing laparoscopically assisted vaginal hysterectomy. Ambulatory Anesthesiology, 106(5), 1402-1406.

$\begin{array}{llll}\text { Postoperative Nausea and } & \underline{\text { Pain Scores }} & \underline{\text { Adverse Side Effects }} & \underline{\text { Limitations }}\end{array}$

In Group S, 49 patients (65\%) experienced PONV. In Group D, 28 patients (36\%); Group H 27 patients (37\%); Group Dx 28 patients (38\%); Group H + Dx 14 patients (19\%) experienced PONV $(\mathrm{p}=0.05)$.
All groups reported VAS scores of 2-4 on a scale of 0 10. There was no significant differences determined between groups.
Group D had two patients that experienced EPS, motor restlessness. Group H had one patient that experienced motor restlessness. No statistical significant differences were determined between groups.
The results are not sensitive enough to detect the antinausea effect of the antiemetics tested because the authors did not use a VAS score to evaluate the nausea severity. 


\begin{tabular}{|c|c|c|c|}
\hline Postoperative Nausea and & Pain Scores & Adverse Side Effects & Limitations \\
\hline $\begin{array}{l}\text { Vomiting } \\
\text { Group H had } 25 \text { patients } \\
\text { (39\%) experience PONV; } \\
\text { Group O had } 25 \text { patients } \\
(38 \%) ; \text { and Group } \mathrm{H}+\mathrm{O} \text { had } \\
13 \text { patients }(21 \%)(\mathrm{p}<0.05) \text {. }\end{array}$ & $\begin{array}{l}\text { Using the VAS, with a score } \\
\text { range from } 0-10 \text {, Group } \mathrm{H} \\
\text { scored } 2.2 \pm 1.4 \text {; Group } \mathrm{O} \\
\text { scored } 2.1 \pm 1.3 \text {; Group } \mathrm{H}+ \\
\text { O scored } 1.9 \pm 0.8 \text {. }\end{array}$ & $\begin{array}{l}\text { Two patients reported an } \\
\text { EPS of restlessness. One was } \\
\text { in Group } \mathrm{H} \text {, and one was in } \\
\text { Group } \mathrm{H}+\mathrm{O} \text {. }\end{array}$ & $\begin{array}{l}\text { No control group was used in } \\
\text { this study. }\end{array}$ \\
\hline
\end{tabular}




\begin{tabular}{|c|c|c|c|}
\hline \multicolumn{4}{|c|}{$\begin{array}{l}\text { D-4: Joo, J., Park, Y., Baek, J., \& Moon, Y. (2015). Haloperidol dose combined with dexamethasone for ponv prophylaxis } \\
\text { in high-risk patients undergoing a gynecological laparoscopic surgery: a prospective, randomized, double-blind, dose- } \\
\text { response and placebo-controlled study. BMC Anesthesiology, 15(99), 1-6. }\end{array}$} \\
\hline \multicolumn{4}{|c|}{$\begin{array}{llll}\text { Postoperative Nausea and } & \underline{\text { Pain Scores }} & \text { Adverse Side Effects } & \underline{\text { Limitations }}\end{array}$} \\
\hline $\begin{array}{l}\text { In Group H0 } 21 \text { patients } \\
\text { (42\%) experienced PONV; } \\
\text { Group H1 had } 11 \text { patients } \\
\text { (22\%); and Group H2 had } 10 \\
\text { patients (20\%) who } \\
\text { experienced PONV } \\
(\mathrm{p}<0.017) \text {. }\end{array}$ & $\begin{array}{l}\text { Group H0 reported an } \\
\text { average VAS score of 2.2; } \\
\text { Group H1 reported 2.8; } \\
\text { Group H2 reported 2.2. }\end{array}$ & $\begin{array}{l}\text { There was no significant } \\
\text { difference in sedation scores } \\
\text { between Group H0 and H1, } \\
\text { average on the VAS score } \\
\text { was a } 3.5 \text {. There was an } \\
\text { increased sedation scores in } \\
\text { Group H2, where the average } \\
\text { VAS score was a } 5 \\
\text { (p<0.001). No cardiac } \\
\text { arrhythmias or EPS were } \\
\text { observed. }\end{array}$ & $\begin{array}{l}\text { There was no control group, } \\
\text { as all patients received } \\
\text { dexamethasone. } \\
\text { Relatively small sample size, } \\
\text { leading to these results being } \\
\text { exploratory rather than } \\
\text { confirmatory results. }\end{array}$ \\
\hline
\end{tabular}




\begin{tabular}{|c|c|c|c|}
\hline \multicolumn{4}{|c|}{$\begin{array}{l}\text { D-5: Wang, T., Liu, Y., Chu, C., Shieh, J., Tzeng, J., \& Wang, J. (2008). Low-dose haloperidol prevents post-operative } \\
\text { nausea and vomiting after ambulatory laparoscopic surgery. Acta Anaesthesiologica Scandinavica, 52, 280-284. }\end{array}$} \\
\hline $\begin{array}{l}\text { Postoperative Nausea and } \\
\text { Vomiting }\end{array}$ & $\underline{\text { Postoperative Pain Score }}$ & $\underline{\text { Adverse Side Effects }}$ & $\underline{\text { Limitations }}$ \\
\hline $\begin{array}{l}\text { In the haloperidol group } 14 \\
\text { patients ( } 31 \% \text { ) experienced } \\
\text { PONV; the droperidol group } \\
\text { had } 14 \text { patients ( } 32 \% \text { ) and } \\
\text { the saline group had } 29 \\
\text { patients (62\%) who } \\
\text { experienced PONV ( }<<0.05) \text {. }\end{array}$ & $\begin{array}{l}\text { Pain reports were } 1-3 \text { in all } \\
\text { three groups with no } \\
\text { differences found between } \\
\text { them. }\end{array}$ & $\begin{array}{l}\text { The level of sedation was } \\
\text { scored } 1-2 \text { in all three } \\
\text { groups, with no differences } \\
\text { found. There were no } \\
\text { observed EPS in any group. }\end{array}$ & $\begin{array}{l}\text { Due to the fact that this study } \\
\text { was done with ambulatory } \\
\text { surgery, the authors had to } \\
\text { rely on getting information } \\
\text { on the phone after the patient } \\
\text { was discharged and not } \\
\text { actual observed results. }\end{array}$ \\
\hline
\end{tabular}




\section{Appendix E}

Critical Appraisal Skills Programme (CASP) Randomized Control Trials Checklist

E-1: Benevides, M. L., Oliveira, S., \& Aguilar-Nascimento, J. E., (2012). Combination of haloperidol, dexamethasone, and ondansetron reduces nausea and pain intensity and morphine consumption after laparoscopic sleeve gastrectomy. Revista Brasileira De Anestesiologia, 63(5), 404-409.

\begin{tabular}{|c|c|c|c|}
\hline A) Are the results of the trial valid? & YES & $\begin{array}{l}\text { CAN'T } \\
\text { TELL }\end{array}$ & NO \\
\hline $\begin{array}{l}\text { 1. Did the trial address a clearly focused } \\
\text { issue? }\end{array}$ & $\mathrm{X}$ & & \\
\hline $\begin{array}{l}\text { 2. Was the assignment of patients to } \\
\text { treatments randomized? }\end{array}$ & $\mathrm{X}$ & & \\
\hline $\begin{array}{l}\text { 3. Were all of the patients who entered the } \\
\text { trial properly accounted for at its } \\
\text { conclusion? }\end{array}$ & $\mathrm{X}$ & & \\
\hline $\begin{array}{l}\text { 4. Were patients, health workers and study } \\
\text { personnel "blind" to treatment? }\end{array}$ & $\mathrm{X}$ & & \\
\hline $\begin{array}{l}\text { 5. Were the groups similar at the start of } \\
\text { the trial? }\end{array}$ & $\mathrm{X}$ & & \\
\hline $\begin{array}{l}\text { 6. Aside from the experimental } \\
\text { intervention, were the groups treated } \\
\text { equally? }\end{array}$ & $\mathrm{X}$ & & \\
\hline
\end{tabular}

\section{B) What are the results?}

7. How large was the treatment effect? Not discussed.

8. How precise was the estimate of the Not discussed. treatment effect?

\section{C) Will the results help locally?}

9. Can the results be applied in your context?

(or to the local population?)

10. Were all clinically important outcomes considered?

11. Are the benefits worth the harms and costs?

Note. This study did not mention if there were any adverse side effects of haloperidol noted. 
Critical Appraisal Skills Programme (CASP) Randomized Control Trials Checklist

E-2: Chu, C., Shieh, J., Tzeng, J., Chen, J., Lee, Y., Ho, S., \& Wang, J. (2008). The prophylactic effect of haloperidol plus dexamethasone on postoperative nausea and vomiting in patients undergoing laparoscopically assisted vaginal hysterectomy. Ambulatory Anesthesiology, 106(5), 1402-1406.

\begin{tabular}{|c|c|c|c|}
\hline A) Are the results of the trial valid? & YES & $\begin{array}{l}\text { CAN'T } \\
\text { TELL }\end{array}$ & NO \\
\hline $\begin{array}{l}\text { 1. Did the trial address a clearly focused } \\
\text { issue? }\end{array}$ & $X$ & & \\
\hline $\begin{array}{l}\text { 2. Was the assignment of patients to } \\
\text { treatments randomized? }\end{array}$ & $X$ & & \\
\hline $\begin{array}{l}\text { 3. Were all of the patients who entered the } \\
\text { trial properly accounted for at its } \\
\text { conclusion? }\end{array}$ & $X$ & & \\
\hline $\begin{array}{l}\text { 4. Were patients, health workers and study } \\
\text { personnel "blind" to treatment? }\end{array}$ & $X$ & & \\
\hline $\begin{array}{l}\text { 5. Were the groups similar at the start of } \\
\text { the trial? }\end{array}$ & X & & \\
\hline $\begin{array}{l}\text { 6. Aside from the experimental } \\
\text { intervention, were the groups treated } \\
\text { equally? }\end{array}$ & $X$ & & \\
\hline
\end{tabular}

\section{B) What are the results?}

7. How large was the treatment effect? Not discussed.

8. How precise was the estimate of the Not discussed. treatment effect?

\section{C) Will the results help locally?}

9. Can the results be applied in your context?

(or to the local population?)

10. Were all clinically important outcomes considered?

11. Are the benefits worth the harms and costs?

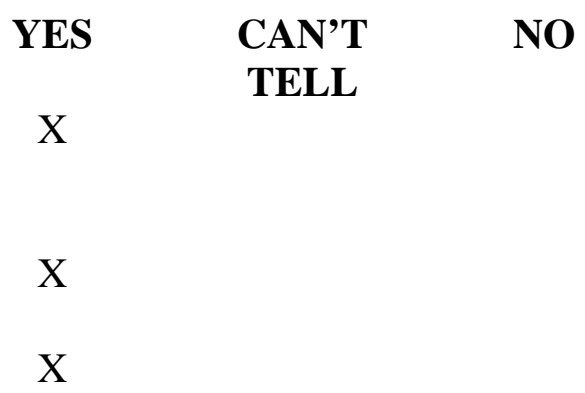


Critical Appraisal Skills Programme (CASP) Randomized Control Trials Checklist

E-3: Feng, P., Chu, K., Lu, I., Shieh, J., Tzeng, J., Ho, S., ... Chu, C. (2009).

Haloperidol plus ondansetron prevents postoperative nausea and vomiting in patients undergoing laparoscopic cholecystectomy. Acta Anaesthesiol Taiwan, 47(1), 3-9.

A) Are the results of the trial valid?

1. Did the trial address a clearly focused issue?

2. Was the assignment of patients to treatments randomized?

3. Were all of the patients who entered the trial properly accounted for at its conclusion?

4. Were patients, health workers and study personnel "blind" to treatment?

5 . Were the groups similar at the start of the trial?

6. Aside from the experimental intervention, were the groups treated equally?

\section{B) What are the results?}

7. How large was the treatment effect?

8. How precise was the estimate of the treatment effect?

\section{C) Will the results help locally?}

9. Can the results be applied in your context?

(or to the local population?)

10. Were all clinically important outcomes considered?

11. Are the benefits worth the harms and costs?
YES

CAN'T

TELL
$\mathrm{X}$

$\mathrm{X}$

$\mathrm{X}$

X

$\mathrm{X}$

X

Not discussed.

Not discussed.

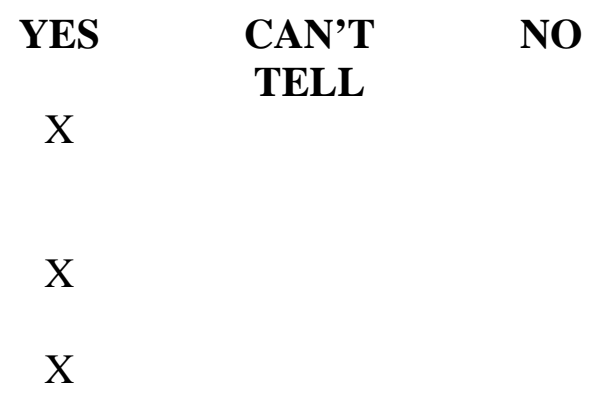


Critical Appraisal Skills Programme (CASP) Randomized Control Trials Checklist

E-4: Joo, J., Park, Y., Baek, J., \& Moon, Y. (2015). Haloperidol dose combined with dexamethasone for ponv prophylaxis in high-risk patients undergoing a gynecological laparoscopic surgery: a prospective, randomized, double-blind, dose-response and placebo-controlled study. BMC Anesthesiology, 15(99), 1-6.

\begin{tabular}{lccc}
\hline A) Are the results of the trial valid? & YES & CAN'T & NO \\
& TELL &
\end{tabular}

1. Did the trial address a clearly focused $\quad \mathrm{X}$ issue?

2. Was the assignment of patients to $X$ treatments randomized?

3. Were all of the patients who entered the $\quad X$ trial properly accounted for at its conclusion?

4. Were patients, health workers and study X personnel "blind" to treatment?

5. Were the groups similar at the start of $\quad X$ the trial?

6. Aside from the experimental $\mathrm{X}$ intervention, were the groups treated equally?

\section{B) What are the results?}

7. How large was the treatment effect? Not discussed.

8. How precise was the estimate of the Not discussed. treatment effect?

\section{C) Will the results help locally?}

9. Can the results be applied in your context?

(or to the local population?)

10. Were all clinically important outcomes $\quad \mathrm{X}$ considered?

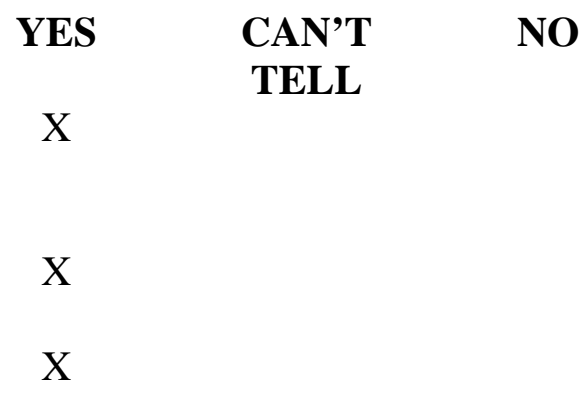
costs? 
Critical Appraisal Skills Programme (CASP) Randomized Control Trials Checklist

E-5: Wang, T., Liu, Y., Chu, C., Shieh, J., Tzeng, J., \& Wang, J. (2008). Low-dose haloperidol prevents post-operative nausea and vomiting after ambulatory laparoscopic surgery. Acta Anaesthesiologica Scandinavica, 52, 280-284.
A) Are the results of the trial valid?
YES
1. Did the trial address a clearly focused issue?
2. Was the assignment of patients to treatments randomized?
3. Were all of the patients who entered the trial properly accounted for at its conclusion?
4. Were patients, health workers and study personnel "blind" to treatment?
5 . Were the groups similar at the start of the trial?
6. Aside from the experimental intervention, were the groups treated equally?
$\mathrm{X}$
$\mathrm{X}$
$\mathrm{X}$
$\mathrm{X}$
$\mathrm{X}$
$\mathrm{X}$

CAN'T

NO

TELL

\section{B) What are the results?}

7. How large was the treatment effect? Not discussed.

8. How precise was the estimate of the treatment effect?

Not discussed.

\section{C) Will the results help locally?}

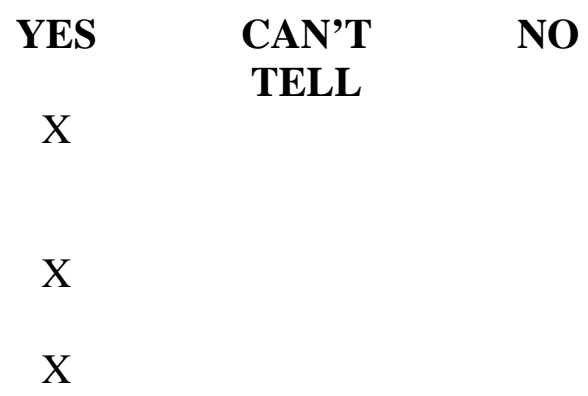

9. Can the results be applied in your context?

(or to the local population?)

10. Were all clinically important outcomes considered?

11. Are the benefits worth the harms and costs? 


\section{Appendix F}

Cross-Study Results Analysis

\begin{tabular}{|c|c|c|c|}
\hline Study number & Nausea \& Vomiting & Pain Scores & Adverse Side Effects \\
\hline 1 & $\begin{array}{l}\text { There was a decrease in nausea } \\
\text { intensity and episodes of vomiting } \\
\text { in the group medicated with } \\
\text { haloperidol. }\end{array}$ & $\begin{array}{l}\text { There was a decrease in VAS } \\
\text { pain scores in the group } \\
\text { medicated with haloperidol. }\end{array}$ & None noted in this study. \\
\hline 2 & $\begin{array}{l}\text { There was a decrease in PONV } \\
\text { when patients were medicated with } \\
\text { haloperidol, droperidol, or } \\
\text { dexamethasone. There was a further } \\
\text { decrease when they were medicated } \\
\text { with haloperidol and } \\
\text { dexamethasone together. }\end{array}$ & $\begin{array}{l}\text { There was no statistical } \\
\text { difference between groups in } \\
\text { reported pain scores. }\end{array}$ & $\begin{array}{l}\text { Two patients experienced the } \\
\text { EPS of motor restlessness. }\end{array}$ \\
\hline 3 & $\begin{array}{l}\text { There was a significant decrease in } \\
\text { patients medicated with } \\
\text { ondansetron and haloperidol } \\
\text { combined. }\end{array}$ & $\begin{array}{l}\text { There was no statistical } \\
\text { difference between groups in } \\
\text { reported pain scores. }\end{array}$ & $\begin{array}{l}\text { Two patients experienced the } \\
\text { EPS of motor restlessness. }\end{array}$ \\
\hline 4 & $\begin{array}{l}\text { There was a decrease in PONV } \\
\text { when patients were medicated with } \\
\text { haloperidol. }\end{array}$ & $\begin{array}{l}\text { There was no statistical } \\
\text { difference between groups in } \\
\text { reported pain scores. }\end{array}$ & $\begin{array}{l}\text { There were no EPS noted, the } \\
\text { haloperidol group with higher } \\
\text { dosing did experienced } \\
\text { increased sedation. }\end{array}$ \\
\hline 5 & $\begin{array}{l}\text { There was a decreased in PONV } \\
\text { when patients were medicated with } \\
\text { haloperidol or droperidol compared } \\
\text { to saline. }\end{array}$ & $\begin{array}{l}\text { There was no statistical } \\
\text { difference between groups in } \\
\text { reported pain scores. }\end{array}$ & $\begin{array}{l}\text { No adverse side effects } \\
\text { observed in this study. }\end{array}$ \\
\hline
\end{tabular}


